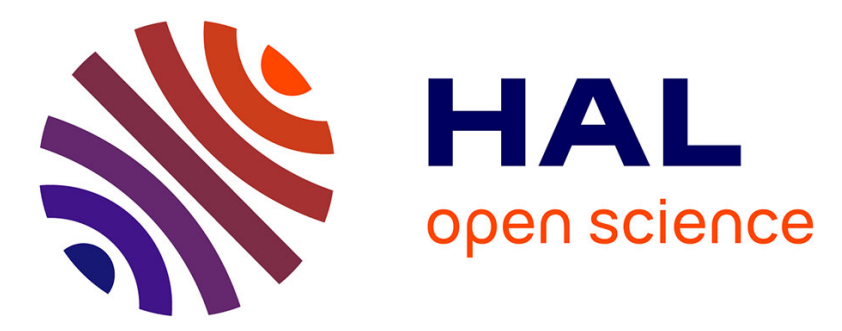

\title{
Cost comparison of advanced oxidation processes for wastewater treatment using accumulated oxygen-equivalent criteria
}

Emmanuel Mousset, Wei Hao Loh, Wei Shien Lim, Léa Jarry, Zuxin Wang, Olivier Lefebvre

\section{To cite this version:}

Emmanuel Mousset, Wei Hao Loh, Wei Shien Lim, Léa Jarry, Zuxin Wang, et al.. Cost comparison of advanced oxidation processes for wastewater treatment using accumulated oxygen-equivalent criteria. Water Research, 2021, 200, pp.117234. 10.1016/j.watres.2021.117234 . hal-03429834

\section{HAL Id: hal-03429834 https://hal.science/hal-03429834}

Submitted on 15 Nov 2021

HAL is a multi-disciplinary open access archive for the deposit and dissemination of scientific research documents, whether they are published or not. The documents may come from teaching and research institutions in France or abroad, or from public or private research centers.
L'archive ouverte pluridisciplinaire HAL, est destinée au dépôt et à la diffusion de documents scientifiques de niveau recherche, publiés ou non, émanant des établissements d'enseignement et de recherche français ou étrangers, des laboratoires publics ou privés.

\section{(ㅇ)(1) $\$$}

Distributed under a Creative Commons Attribution - NonCommercial - NoDerivatives| 4.0 


\section{Cost comparison of advanced oxidation processes for wastewater treatment using accumulated oxygen-equivalent criteria}

Emmanuel Mousset ${ }^{a, b}$, Wei Hao Loh ${ }^{a}$, Wei Shien Limª, Léa Jarry ${ }^{a}$, Zuxin Wang ${ }^{\text {a,c }}$, Olivier Lefebvre*,a

${ }^{a}$ Centre for Water Research, Department of Civil and Environmental Engineering, National University of Singapore, 1 Engineering Dr. 2, Singapore 117576, Singapore

b Laboratoire Réactions et Génie des Procédés, UMR CNRS 7274, Université de Lorraine, 1 rue Grandville BP 20451, 54001 Nancy cedex, France

${ }^{\mathrm{c}}$ School of Civil Engineering and Architecture, Northeast Electric Power University, Jilin 132012, China

\section{Paper accepted in}

\section{Water Research}

*Corresponding author:

E-mail: ceelop@nus.edu.sg; phone:+65 92258267 


\begin{abstract}
Advanced oxidation processes (AOPs) have received a lot of attention over the years as advanced physicochemical polishing wastewater treatments to remove biorefractory pollutants. Additionally, many studies report their excellent degradation and mineralization performance as stand-alone technologies too, demonstrating the versatility of these processes; however, there is a lack of suitable methods to compare the performance (in terms of removal efficiency and operating costs) of different AOPs in the same conditions. In this context, the goal of this paper is to propose a systematic investigation by introducing a novel criterion, namely the accumulated oxygen-equivalent chemical-oxidation dose (AOCD), to systematically compare the diverse AOPs available: ozonation, $\mathrm{H}_{2} \mathrm{O}_{2}$ photolysis, Fenton, photo-Fenton, electro-Fenton and photoelectro-Fenton (paired with anodic oxidation, for the latter two). For each of these, the cost efficiency was determined by optimizing the operating conditions for the removal of phenol, selected as a model pollutant $\left(1.4 \mathrm{mM}\right.$, equivalent to $\left.100 \mathrm{mg}-\mathrm{C} \mathrm{L}^{-1}\right)$. The operating costs considered sludge management, chemical use and electricity consumption. Among all AOPs, electro-Fenton was the most cost-effective $\left(108-125 € \mathrm{~m}^{-3}\right)$, notwithstanding the mineralization target $(50 \%, 75 \%$ and 99\%), owing to its electrocatalytic behavior. Chemical Fenton proved competitive too up to $50 \%$ of mineralization, meaning that it could also be considered as a cost-effective pre-treatment solution. AOCD was the lowest for electro-Fenton, which could be attributed to its excellent faradaic yield, while UV-based processes generally required the highest dose. The AOCD criterion could serve as a baseline for AOP comparison and prove useful for the legislator to determine the "best available techniques" as defined by the Industrial Emissions European Union Directive 2010/75/EU.
\end{abstract}

Keywords: electro-Fenton, Fenton, $\mathrm{H}_{2} \mathrm{O}_{2}$ photolysis, ozonation, photo-Fenton, photoelectro-Fenton 


\section{Introduction}

Many industrial processes generate waste streams contaminated with a variety of organic pollutants, from phenolic compounds to fertilizers and pesticides, that constitute an environmental and public health threat if left untreated (Rodríguez, 2003). Municipal wastewater treatment plants (WWTPs) also release various potentially-toxic micropollutants, such as pharmaceuticals and personal care products, because they are not designed to deal with these biorecalcitrant chemicals (Ghatak, 2013). Though conventional biological treatments are cheaper than physico-chemical technologies, they are not able to completely eliminate these persistent pollutants. Therefore, other processes such as membrane filtration, activated carbon adsorption, ozonation (circum-neutral $\mathrm{pH}$ ) and advanced oxidation processes (AOPs) have been proposed as complementary step in WWTPs to address the challenge of municipal wastewater reuse as mentioned in a recent review (Rizzo et al., 2020). This paper highlights the lack of cost comparison studies between these technologies. Still, the high removal efficiencies (>80-100\%) of xenobiotics compounds obtained with AOPs has been emphasized in the comparative work (Rizzo et al., 2020), which explains the increasing deployment of AOPs as advanced physico-chemical treatments (Oturan and Aaron, 2014). Their combination with a biological treatment to remove the biodegradable fraction is particularly encouraged when possible, to decrease the global cost of the treatment (Mousset et al., 2018c; Mousset et al., 2021; Oller et al., 2011; Olvera-Vargas et al., 2016; Rizzo et al., 2020). For all AOPs, the main oxidant - produced in mild conditions (Buxton et al., 1988) - is the hydroxyl radical ( $\left.{ }^{\circ} \mathrm{OH}\right)$, the strongest oxidizing agent $\left(\mathrm{E}^{\circ}\left({ }^{\circ} \mathrm{OH} / \mathrm{H}_{2} \mathrm{O}\right)\right.$ $=2.80 \mathrm{~V} /$ standard hydrogen electrode $(\mathrm{SHE}))$ after fluorine $\left(\mathrm{E}^{0}\left(\mathrm{~F}_{2} / \mathrm{F}^{-}\right)=3.03 \mathrm{~V} / \mathrm{SHE}\right)$, but less hazardous (Pignatello et al., 1999). ${ }^{\circ} \mathrm{OH}$ radicals are extremely reactive species that attack most organic molecules with rate constants in the range of $10^{8}-10^{10} \mathrm{~L} \mathrm{~mol}^{-1} \mathrm{~s}^{-1}$ towards double carbon bonds, such as aromatic compounds, which constitute the bulk of industrial organic pollutants (Brillas et al., 2009; Castillo-Carvajal et al., 2014; Saien and Shahrezaei, 2012). $\mathrm{OH}$ modes of attack include electrophilic addition, hydrogen abstraction, electron transfer and the recently-identified ipso-substitution mechanism (Mousset et al., 2018a).

AOPs include pure chemical technologies, i.e., Fenton $\left(\mathrm{Fe}^{2+} / \mathrm{H}_{2} \mathrm{O}_{2}\right)$, as well as ozone-based technologies $\left(\mathrm{O}_{3}\right.$ at alkaline $\mathrm{pH}$, peroxonation $\left.\left(\mathrm{O}_{3} / \mathrm{H}_{2} \mathrm{O}_{2}\right)\right)$ and photochemical processes such as photo-Fenton $\left(\mathrm{UV} / \mathrm{Fe}^{2+} / \mathrm{H}_{2} \mathrm{O}_{2}\right)$ and $\mathrm{H}_{2} \mathrm{O}_{2}$ photolysis $\left(\mathrm{UV} / \mathrm{H}_{2} \mathrm{O}_{2}\right)$ (Stefan, 2017). In addition to conventional AOPs, electrochemical AOPs (EAOPs) 
continuously generate ${ }^{\circ} \mathrm{OH}$ in situ through different modes of action depending upon the electrode materials (Garcia-Rodriguez et al., 2020; Moreira et al., 2017). For example, in anodic oxidation, heterogeneous ${ }^{\circ} \mathrm{OH}$ radicals are generated at the surface of a high $\mathrm{O}_{2}$ evolution overvoltage anode (Martínez-Huitle et al., 2015). Meanwhile, electro-Fenton and photoelectro-Fenton involve homogeneous ${ }^{\circ} \mathrm{OH}$ produced in the bulk solution through the electro-generation of $\mathrm{H}_{2} \mathrm{O}_{2}$, generally at a carbon-based cathode and in the presence of $\mathrm{Fe}^{2+}$ ions in solution (Mousset et al., 2016c; Panizza and Cerisola, 2009; Sirés et al., 2014). EAOPs offer the benefits to operate with minimal addition of chemicals; yet, there is a lack of systematic studies comparing the costs of various AOPs under the same conditions and for the same application (Huddersman et al., 2019; Miklos et al., 2018). Furthermore, there is an urgent need to bring comparative data and tools for determining the "best available techniques", as defined by the European Union (Industrial Emissions European Union Directive 2010/75/EU) for the legislator approval and/or for determining standard legal processes to be applied in real conditions (Rizzo et al., 2020). Several papers have attempted to provide a cost comparison of the various AOPs available, a list of which is given as Table S1. One of the most common criteria currently used is the electric energy per order (Bolton et al., 2001; Sgroi et al., 2021; Yao et al., 2018) that takes into account the electric power (including current intensity and cell potential for electrochemical processes, as well as lamp power for photo-processes), the removal efficiency (with ratio of final over initial concentrations, and/or apparent rate constant) and the flow rate. However, this criterion does not take into account reactor design parameters. Another commonly-used parameter is the space-time yield with the advantage to consider the residence time, removal efficiency (including apparent rate constant) and the ideal reactor design such as continuously stirred tank reactor (CSTR) and plug-flow reactor (PFR) (Leblebici et al., 2015). This factor can further be normalized with the power (lamp power for photo-processes) in order to take into account the energy consumption, in which case it is referred to as photocatalytic space-time yield (Leblebici et al., 2015). Though interesting insights are given to compare 14 photo-reactors, this factor could be improved further in order to extend the comparison to a more diverse set of AOPs (including electrochemical AOPs, ozonation, Fenton, etc), by taking into account for example the active surface area, the faradaic or quantum yields, the size and distance of the lamp. Moreover, the chemicals costs should be included alongside energy requirement $\left(\mathrm{kWh} \mathrm{m}^{-3}\right)$ for a more comprehensive overview of the operating costs (Goi and Trapido, 2002; Prieto-Rodríguez 
et al., 2013), while specific energy $\left(\mathrm{kWh} \mathrm{m}^{-3} \mathrm{~g}^{\left.-\mathrm{TOC}^{-1}\right)}\right.$ that includes removal efficiency was considered instead in another work (Lucas et al., 2010). One of the most comprehensive works available in the literature consists of a comparison between advanced electro-oxidation with boron-doped diamond anode (BDD), ozonation and chemical Fenton, including the Fenton sludge management costs (Cañizares et al., 2009). The same paper also introduced the oxygen-equivalent chemical-oxidation capacity (OCC) parameter to enable a suitable comparison of these very distinct AOPs (Cañizares et al., 2009). The $\mathrm{OCC}$ includes the $\mathrm{O}_{3}$ and $\mathrm{H}_{2} \mathrm{O}_{2}$ concentrations, the specific charge and the cell potential, but photo-processes were not taken into account and some relevant engineering parameters were not considered (e.g. residence time, active surface area, faradaic or quantum yields, size and distance of the lamp). It is further noticeable that there exists no comprehensive cost comparison of photo-based, Fenton-based, electrochemical-based and ozone-based AOPs in a single study.

In this context, the objective of this study is to propose a unique and comprehensive comparison at the laboratory scale of AOPs in their broad diversity: ozonation, $\mathrm{H}_{2} \mathrm{O}_{2}$ photolysis, Fenton, photo-Fenton, electro-Fenton and photoelectro-Fenton (the latter too being paired with anodic oxidation). The introduction of a new criterion was proposed - the accumulated oxygen-equivalent chemical-oxidation dose (AOCD) - to facilitate AOP comparison, which could be used in future studies and for legislative and policy purposes. AOCD includes important missing parameters from previous studies (i.e., residence time, current density, irradiance, active surface of the electrodes and lamp, distance of the lamp, faradaic and quantum yields, number of electrons exchanged, wavelength). The operating costs associated with chemical and energy use, as well as sludge management (whenever required) have been calculated after optimization of each processes comprising mineralization kinetics and costs. The overall operating costs were then compared to one another in the optimal conditions for each AOP and for three mineralization targets, $50 \%$ and $75 \%$ for pre-treatment and $99 \%$ for complete treatment. For the purpose of benchmarking processes against one another and also against the literature, phenol was selected as a model organic pollutant, being widely studied in AOP research (Azevedo et al., 2009; Bremner et al., 2006; Brillas and GarciaSegura, 2020; Maciel et al., 2004; Mousset et al., 2016a; Mousset et al., 2017a; Pimentel et al., 2008; Wang et al., 2005). Additionally, phenols are environmentally relevant, due to their wide use in many industrial processes, as intermediates in synthesis or as raw materials for the manufacturing of insecticides, pesticides, wood preservatives, 
etc. (Rahmani et al., 2008; Rodríguez, 2003). Because of the many ways that phenols can be used, they can be found not only in industrial wastewaters but also in soil, groundwater and surface water, following improper waste disposal practices and accidental leakages (Benitez et al., 1999).

\section{Materials and methods}

\subsection{Chemicals}

All chemicals employed in this study were of analytical grade. All solutions were prepared with ultrapure water supplied from RiOs ${ }^{\mathrm{TM}}$ Essential Water Purification System (Millipore, Singapore) with electrical resistivity of 18.2 $\mathrm{M} \Omega \mathrm{cm}$ and total organic carbon (TOC) of $4 \mathrm{ppb}$. For comparison purposes, the same stock phenol solution was used for every experiment at a concentration of $1.4 \mathrm{mM}$ (initial TOC: $\mathrm{TOC}_{0}=100 \mathrm{mg}-\mathrm{C} \mathrm{L} \mathrm{L}^{-1}$ ), which falls within the common range of phenol concentrations found in various industrial wastewater streams (Girish and Murty, 2014).

\subsection{Experimental Setups}

Figure S1a shows the experimental setup of the ozonation reactor, similar to that of a previous study (Lefebvre et al., 2013). An Ozonoia Triogen laboratory ozone generator (Suez Environment, France) was used to produce ozone at the desired concentration from oxygen gas fed to the generator at a rate of $3 \mathrm{~L} \mathrm{~min}^{-1}$. The ozone generator required 42, 63, 74, 84, $105 \mathrm{~W}$ to reach an ozone dose $\left(\left[\mathrm{O}_{3}\right]\right)$ of 102, 204, 246, 300 and $360 \mathrm{mg}(\mathrm{Lh})^{-1}$ respectively, according to the supplier instructions. The ozone generator was connected to a $500-\mathrm{mL}$ glass flask containing the phenol stock solution and connected to a $500-\mathrm{mL}$ gas-washing bottle to trap excess ozone. The ozone dose that reacted in the process was obtained by subtracting the residual dissolved ozone and the excess gaseous ozone from the actual ozone dose (Lefebvre et al., 2013). Figure S1b shows the schematic diagram of the Fenton reactor, involving a magnetic stirrer $(300 \mathrm{rpm})$ and a $600 \mathrm{~mL}$ cylindrical glass reactor. Figure S1c shows the schematic diagram of the quartz photochemical reactor connected to a $600-\mathrm{mL}$ feed tank through a peristaltic pump (Masterflex L/S economy variable-speed drive, USA). The reactor volume was $263 \mathrm{~mL}$ and the UV lamp (Heraeus Noblelight GmbH / TNN 12/20, Germany) irradiated at a wavelength $(\lambda)$ of $254 \mathrm{~nm}$, the optimal wavelength for 
attacking double $\mathrm{C}=\mathrm{C}$ bonds present in a majority of biorecalcitrant organic pollutants (Stefan, 2017). The reactor was operated in recirculated batch mode at a flow rate of $0.4 \mathrm{~L} \mathrm{~min}^{-1}$. Homogeneous mixing was ensured by stirring at $300 \mathrm{rpm}$. The phenol solution was stirred in the feed tank and continuously recirculated in the photo-reactor. For $\mathrm{UV}$ and $\mathrm{UV} / \mathrm{H}_{2} \mathrm{O}_{2}$ experiments, the $\mathrm{pH}$ was not adjusted ( $\mathrm{pH}$ around 6), since the influence of $\mathrm{pH}$ is negligible for those processes (Stefan, 2017), whereas it was a criterion for photo-Fenton experiments. Figure S1d depicts the schematic diagram of the (photo)-electrochemical reactor, differing from the photo-reactor setup by a pair of electrodes placed in the feed tank. The anode was a BDD material (Condias, Germany) $\left(40 \mathrm{~cm}^{2}\right.$ of geometric surface area) and the cathode was a polyacrylonitrile carbon fiber shaped as a brush (SGL group, USA) $\left(80 \mathrm{~cm}^{2}\right.$ of projected surface area) prepared according to our previous study (Mousset et al., 2017b). These electrodes were connected to a power supply (HAMEG 7042-5, Germany). For electro-Fenton, the UV lamp was turned off. Sufficient ionic strength was ensured by the addition of $50 \mathrm{mM}$ of $\mathrm{K}_{2} \mathrm{SO}_{4}$. An air diffuser was added to provide the oxygen for the electro-catalytic production of $\mathrm{H}_{2} \mathrm{O}_{2}$ from $\mathrm{O}_{2}$ reduction at the cathode.

\subsection{Analytical procedures}

The solution $\mathrm{pH}$ was measured with a Horiba F-54BW (Japan) pH meter. The actual ozone output from the ozone generator was determined using the potassium iodide (KI) wet-chemistry method (Rakness et al., 1996). The residual ozone in solution was determined by the indigo colorimetric method (Lefebvre et al., 2013). $\mathrm{H}_{2} \mathrm{O}_{2}$ quenching before analysis was done using a solution of $\mathrm{Na}_{2} \mathrm{~S}_{2} \mathrm{O}_{3}$ at a ratio of two moles of $\mathrm{Na}_{2} \mathrm{~S}_{2} \mathrm{O}_{3}$ per mole of $\mathrm{H}_{2} \mathrm{O}_{2}$ (Liu et al., 2003). High Performance Liquid Chromatography (HPLC) (Shimadzu SCL-10A, Japan) was used to detect phenol, following the method of (Mousset et al., 2016a). The mobile phase consisted of $75 \%$ acetic acid $(1: 100) \mathrm{v} / \mathrm{v}$ of acetic acid/ultrapure water buffer and 25\% methanol (HPLC grade). The column was a Zorbax Extend C18 (15 cm length, $5 \mu \mathrm{m}$ of stationary phase thickness) (Agilent, USA), and the temperature of the oven was set at $40^{\circ} \mathrm{C}$ for analysis. A diode array detector (Shimadzu SPD-M10A, Japan) was set at $280 \mathrm{~nm}$ to detect the presence of phenol at maximal absorbance. Phenol mineralization was monitored by TOC removal (Mousset et al., 2014), determined on a Shimadzu TOC-V $\mathrm{V}_{\mathrm{CSH}}$ analyzer (Japan) by thermal catalytic oxidation $\left(680^{\circ} \mathrm{C}\right)$ (Mousset et al., 2016a). 
The mass of sludge generated by Fenton-based processes was determined by increasing the $\mathrm{pH}$ to 8 with $1 \mathrm{M}$ of $\mathrm{NaOH}$, which led to the precipitation of $\mathrm{Fe}(\mathrm{OH})_{3}$, following a previous methodology (Benatti and Tavares, 2012). The particles in the mixture were left to settle for at least $15 \mathrm{~h}$ to allow complete precipitation of the ferric hydroxide residue, followed by vacuum filtration and drying of the filter disks containing the iron residues in an oven at $105^{\circ} \mathrm{C}$ overnight. The filter disks were then weighed to determine the mass of the total suspended solids (TSS) content (mg L-1) (Degen and Nussberger, 1956).

\subsection{Cost calculations}

Power, chemicals and sludge management cost calculations are detailed in Text S1. 


\section{Results and discussion}

\subsection{Performance and optimization of six AOPs to mineralize phenol}

\subsubsection{Ozonation}

The ozone dose was first optimized at $\mathrm{pH}$ 7, where the main mechanism responsible for phenol oxidation was by electrophilic reaction, in particular at the para- and ortho- positions (Mvula and Von Sonntag, 2003) (Fig. 1a). TOC removal measured at $160 \mathrm{~min}$ increased with the ozone dose from $33 \%$ at $102 \mathrm{mg}$ (Lh) ${ }^{-1}$ to $63 \%$ at $360 \mathrm{mg}$ $(\mathrm{Lh})^{-1}$. The TOC decay rates followed a pseudo-first-order kinetic model $\left(\mathrm{k}_{(1 \mathrm{st} \text { order })}\right)\left(\mathrm{R}^{2}>0.9812\right)$ and increased with the ozone dose from $0.0022 \pm 0.0003 \mathrm{~min}^{-1}$ at $102 \mathrm{mg}(\mathrm{Lh})^{-1}$ to $0.0062 \pm 0.0002 \mathrm{~min}^{-1}$ at $360 \mathrm{mg}$ (Lh) (inset $^{-1}$ panel of Fig. 1a). Because the improvement was marginal when increasing the ozone dose from $300 \mathrm{mg}(\mathrm{Lh})^{-1}$ to $360 \mathrm{mg}(\mathrm{Lh})^{-1}$ (Fig. 1a), the operating costs were the lowest at $300 \mathrm{mg}(\mathrm{Lh})^{-1}$, reaching $1.08 \pm 0.004 € \mathrm{~g}^{-\mathrm{TOC}^{-1}}$ (Fig. 1b), confirming that the optimal ozone dose was indeed $300 \mathrm{mg}(\mathrm{Lh})^{-1}$. 
(a)

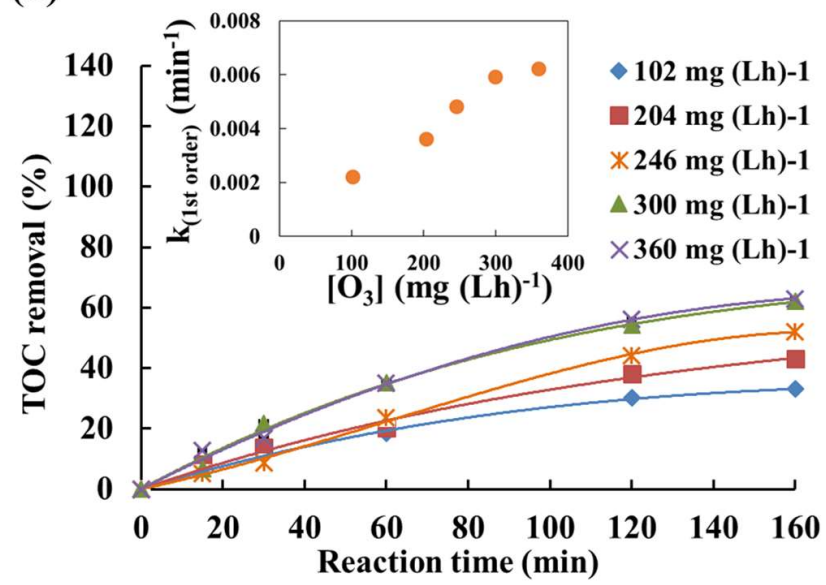

(c)

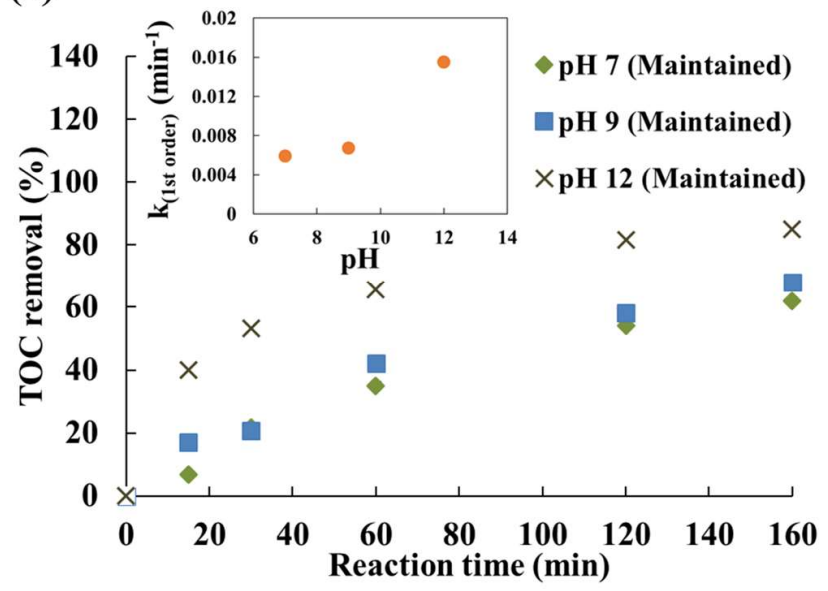

(b)

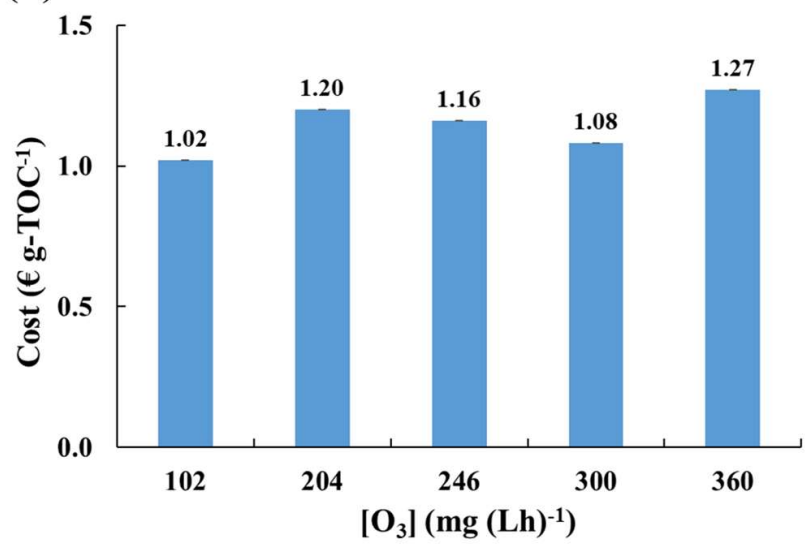

(d)

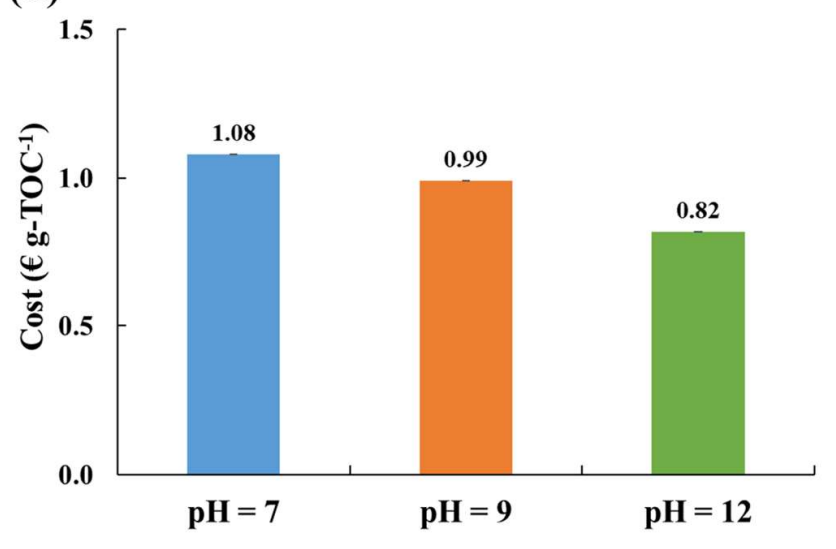

Fig. 1. Ozonation process optimization: (a) TOC removal at different $\left[\mathrm{O}_{3}\right]$ (inset panel: $\mathrm{k}_{(1 \mathrm{st} \text { order) }}$ ) at $\mathrm{pH}$ 7, (b) cost efficiency at different $\left[\mathrm{O}_{3}\right]$ after $160 \mathrm{~min}$, (c) TOC removal at different $\mathrm{pH}$, maintained constant during the experiment (inset panel: $\mathrm{k}_{(1 \mathrm{st} \text { order })}$ ) at $\left[\mathrm{O}_{3}\right]=300 \mathrm{mg}(\mathrm{Lh})^{-1}$, (d) cost efficiency at different initial $\mathrm{pH}$ after 160 $\min$.

The impact of $\mathrm{pH}$ is of course crucial for ozonation and thus was evaluated next by maintaining it at either 7, 9 or 12 , yielding TOC removal at $160 \mathrm{~min}$ of $62 \%, 68 \%$ and $85 \%$, respectively (Fig. 1c). Accordingly, the $\mathrm{k}_{(1 \mathrm{st} \text { order) }}$ values increased with the $\mathrm{pH}$ from $0.0059 \pm 0.0002 \mathrm{~min}^{-1}$ at $\mathrm{pH} 7$ to $0.0155 \pm 0.0003 \mathrm{~min}^{-1}$ at $\mathrm{pH} 12$ (inset panel of Fig. 1c). A considerable increase of mineralization efficiency was thus observed in alkaline conditions, where 
ozone is decomposed in water into ${ }^{\circ} \mathrm{OH}$ radicals, which improved the mineralization efficiency (Stefan, 2017). However, maintaining the $\mathrm{pH}$ at 12 involves additional chemical costs to first adjust the $\mathrm{pH}$ to 12 and then neutralize it back at the end of the treatment. The cost efficiency was thus evaluated for the different $\mathrm{pH}$ tested, taking into account the power consumption and chemical costs (Fig 1d). Increasing the solution pH from 7 to 12

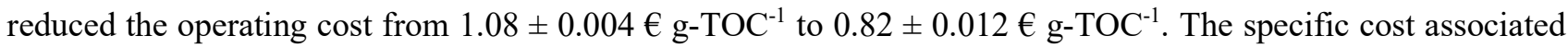
with a $\mathrm{pH}$ of 12 was thus lower than that obtained at lower $\mathrm{pH}$ values, showing that the higher efficiency effectively counterbalanced the increased chemical cost. In conclusion, the optimal conditions for ozonation consisted of a dose of $300 \mathrm{mg}(\mathrm{Lh})^{-1}$ and a $\mathrm{pH}$ maintained at 12.

\subsection{2. $\mathrm{UV} / \mathrm{H}_{2} \mathrm{O}_{2}$}

Figure 2a displays the TOC removal efficiency by $\mathrm{UV} / \mathrm{H}_{2} \mathrm{O}_{2}$ at different $\mathrm{H}_{2} \mathrm{O}_{2}$ concentrations from 0 up to $20 \mathrm{mM}$. In direct photolysis (UV alone), only 5\% of phenol mineralization was achieved after $160 \mathrm{~min}$, showing its limitations for phenol mineralization, in agreement with the literature (Rodríguez, 2003). Comparatively, $\mathrm{UV} / \mathrm{H}_{2} \mathrm{O}_{2}$ experiments depicted higher mineralization yields up to $17 \%$ after 160 min using $17 \mathrm{mM}$ of $\mathrm{H}_{2} \mathrm{O}_{2}$. Accordingly, the $\mathrm{k}_{(1 \text { st order })}\left(\mathrm{R}^{2}>0.9847\right)$ also increased with $\mathrm{H}_{2} \mathrm{O}_{2}$ concentration until $17.0 \mathrm{mM}\left(0.0097 \pm 0.0002 \mathrm{~min}^{-1}\right)$, then decreased at higher concentration (inset panel of Fig. 2a). The cost comparison to determine the optimal operating conditions for the $\mathrm{UV} / \mathrm{H}_{2} \mathrm{O}_{2}$ process is displayed in Fig. 2b, confirming that $\mathrm{UV} / \mathrm{H}_{2} \mathrm{O}_{2}$ was the most cost-effective at $17 \mathrm{mM}$ of $\mathrm{H}_{2} \mathrm{O}_{2}\left(1.37 \pm 0.09 € \mathrm{~g}-\mathrm{TOC}^{-1}\right)$. 


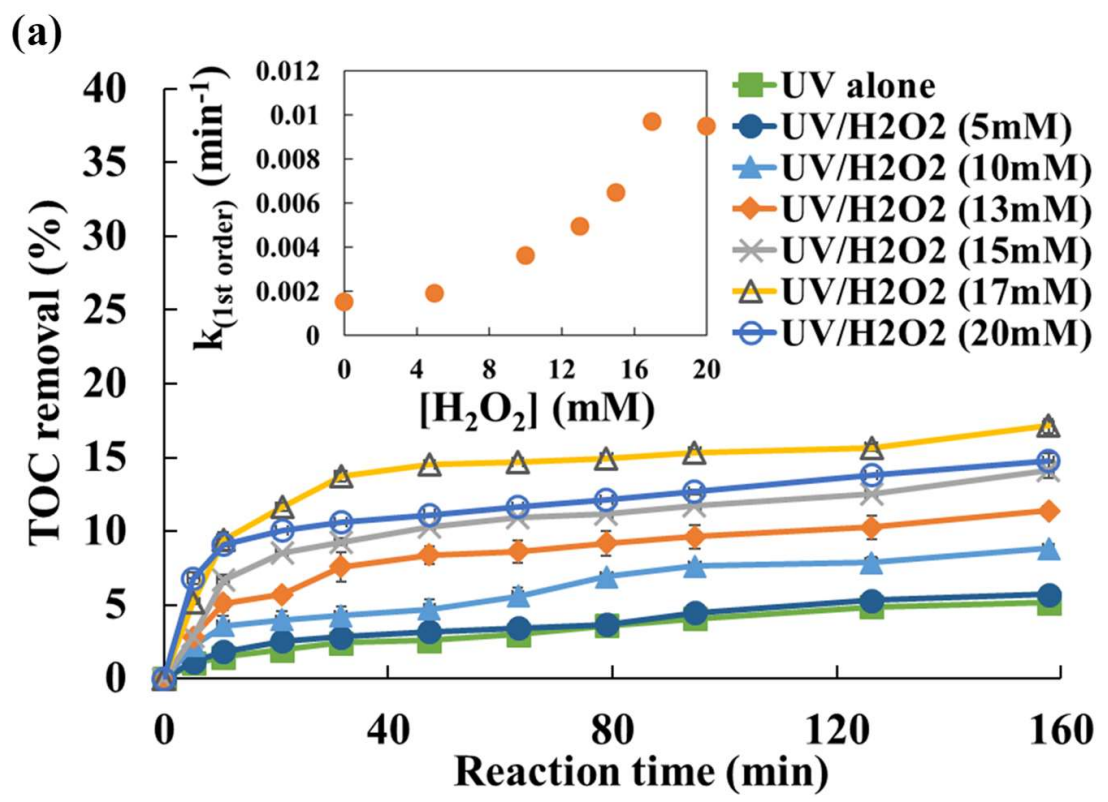

(b)

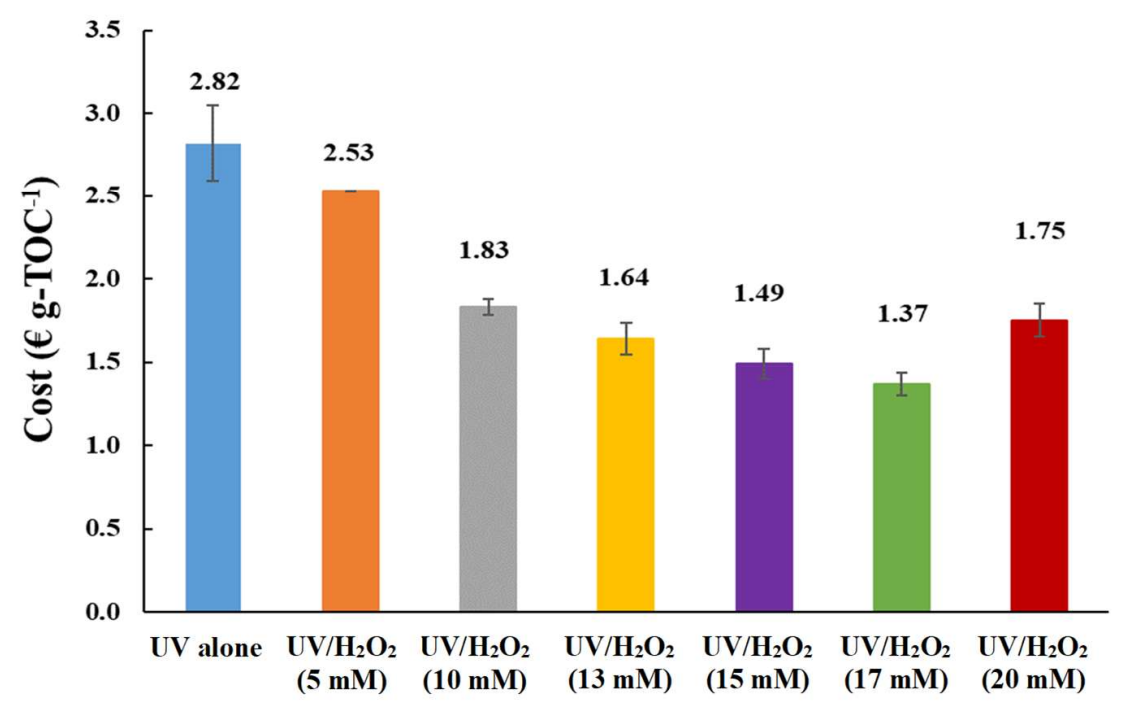

Fig. 2. $\mathrm{UV} / \mathrm{H}_{2} \mathrm{O}_{2}$ process optimization: (a) TOC removal at different $\mathrm{H}_{2} \mathrm{O}_{2}$ concentrations (inset panel: $\mathrm{k}_{(1 \mathrm{st} \text { order) }}$ at different $\mathrm{H}_{2} \mathrm{O}_{2}$ concentrations) (operating conditions: $\mathrm{pH}$ 7, $\lambda=254 \mathrm{~nm}$ ), (b) cost efficiency at different $\mathrm{H}_{2} \mathrm{O}_{2}$ concentrations at $160 \mathrm{~min}$ (cost: electric power and chemicals). 


\subsubsection{Chemical Fenton}

Fenton processes are largely dependent on the concentration of $\mathrm{H}_{2} \mathrm{O}_{2}\left(\left[\mathrm{H}_{2} \mathrm{O}_{2}\right]\right)$ and $\mathrm{Fe}^{2+}\left(\left[\mathrm{Fe}^{2+}\right]\right)$, the impact of which is shown in Figs. $3 \mathrm{a}$ and $3 \mathrm{~b}$. The mineralization efficiency increased up to $15.0 \mathrm{mM}$ of $\mathrm{H}_{2} \mathrm{O}_{2}$ and $0.9 \mathrm{mM}$ of $\mathrm{Fe}^{2+}$, then reached a plateau at around $46 \%$ of TOC removal towards the end of the experiment (Figs. 3a and 3b). At this optimal $\mathrm{Fe}^{2+} / \mathrm{H}_{2} \mathrm{O}_{2}$ ratio of $0.06, \mathrm{k}_{(1 \text { st order })}\left(\mathrm{R}^{2}>0.9835\right)$ was the highest, reaching $0.0372 \pm 0.0003 \mathrm{~min}^{-}$

${ }^{1}$ (inset panel of Figs. 3a and 3b). An excess of $\mathrm{H}_{2} \mathrm{O}_{2}$ can generate the less reactive hydroperoxy-radicals, known to inhibit the oxidation process (Chen and Pignatello, 1997), while an excess of $\mathrm{Fe}^{2+}$ favors secondary reactions that limit the ${ }^{\circ} \mathrm{OH}$ production rate (Brillas et al., 2009). Additionally, increasing $\mathrm{Fe}^{2+}$ concentration without any significant gain of TOC removal would represent an unnecessary cost and possibly a threat to aquatic life, as well as an increase in production of ferric hydroxide $\left(\mathrm{Fe}(\mathrm{OH})_{3}\right)$ sludge that would then need to be disposed, following final pH adjustment, again adding to the cost of treatment and reagents (A. Sychev, 1995; Cañizares et al., 2009). By varying the $\mathrm{Fe}^{2+} / \mathrm{H}_{2} \mathrm{O}_{2}$ ratio, the operating costs taking into account sludge management and chemicals, were found to first decrease from $0.101 \pm 0.0006 € \mathrm{~g}-\mathrm{TOC}^{-1}\left(\mathrm{Fe}^{2+} / \mathrm{H}_{2} \mathrm{O}_{2}=0.01\right)$ to a minimal of $0.041 \pm 0.0003 € \mathrm{~g}-$ $\mathrm{TOC}^{-1}\left(\mathrm{Fe}^{2+} / \mathrm{H}_{2} \mathrm{O}_{2}=0.06\right)$ and then increased again (Fig. 3c). A Fe ${ }^{2+} / \mathrm{H}_{2} \mathrm{O}_{2}$ ratio of 0.06 was thus deemed the most cost-effective, in agreement with the TOC decay rates (Figs. 3a-3b). 
(a)

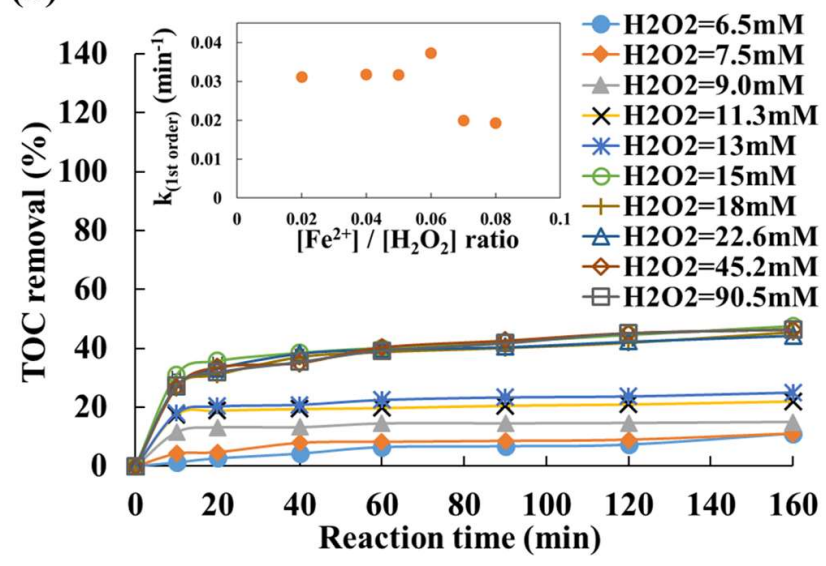

(c)

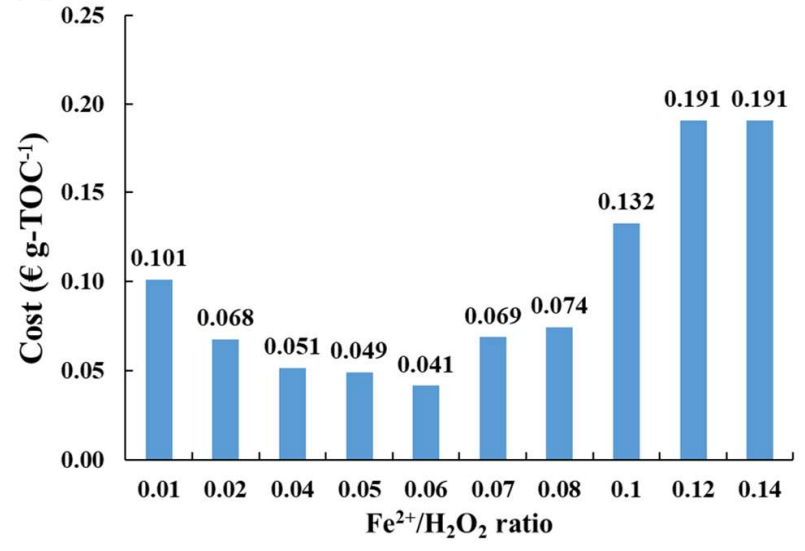

(b)

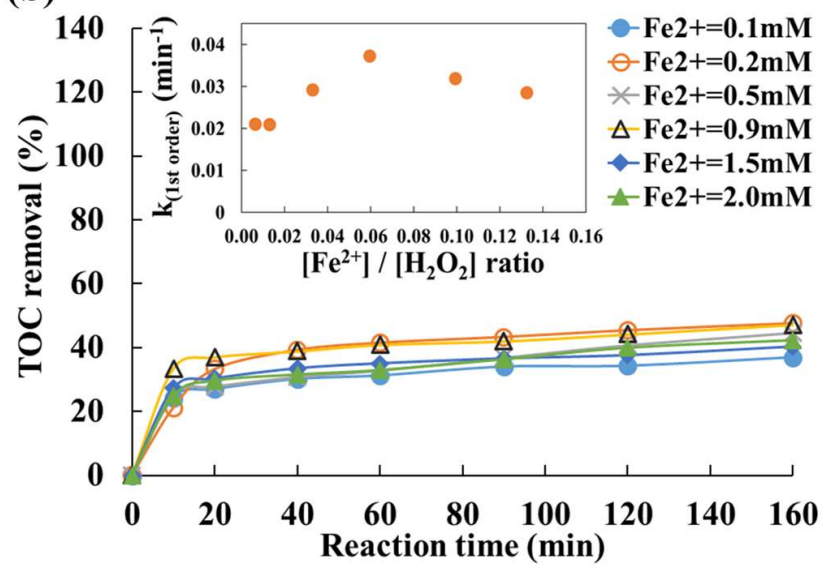

(d)

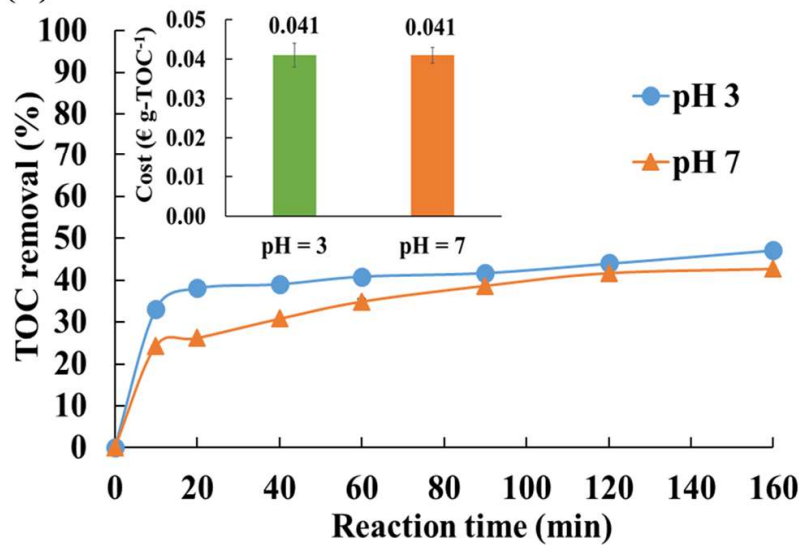

Fig. 3. Fenton process optimization: (a) TOC removal at different $\left[\mathrm{H}_{2} \mathrm{O}_{2}\right]$ (inset panel: $\mathrm{k}_{(1 \text { st order })}$ ) at $\left[\mathrm{Fe}^{2+}\right]=0.9$ $\mathrm{mM}$, (b) TOC removal at different $\left[\mathrm{Fe}^{2+}\right]$ (inset panel: $\mathrm{k}_{(1 \mathrm{st} \text { order) }}$ ) at $\left[\mathrm{H}_{2} \mathrm{O}_{2}\right]=15 \mathrm{mM}$, (c) cost efficiency at different $\mathrm{Fe}^{2+} / \mathrm{H}_{2} \mathrm{O}_{2}$ ratios after $160 \mathrm{~min}$, (d) TOC removal at different initial $\mathrm{pH}$ (inset panel: cost efficiency after $160 \mathrm{~min}$ ) at $\mathrm{Fe}^{2+} / \mathrm{H}_{2} \mathrm{O}_{2}$ ratio $=0.06$.

As a final step, the impact of the $\mathrm{pH}$ was tested at two different values of 3 and 7 at the optimal $\mathrm{Fe}^{2+} / \mathrm{H}_{2} \mathrm{O}_{2}$ ratio. In both cases, the $\mathrm{pH}$ stabilized around 3 after a few minutes (data not shown), as phenol was quickly degraded into carboxylic acids, with acid dissociation constants $\left(p K_{a}\right)$ ranging from 3 to 4 (Mousset et al., 2016a). Unsurprisingly, the TOC removal efficiency was thus similar in both cases, reaching $48 \%$ and $43 \%$ after $160 \mathrm{~min}$ for $\mathrm{pH} 3$ and $\mathrm{pH} 7$, respectively (Fig. 3d), while $\mathrm{k}_{(1 \text { st order) }}$ decreased from $0.0372 \pm 0.0003 \mathrm{~min}^{-1}$ to $0.0279 \pm 0.0002$ $\mathrm{min}^{-1}$. From an application point of view these results suggest that it could theoretically be possible to deal with 
effluents at circum-neutral $\mathrm{pH}$ without initial $\mathrm{pH}$ adjustments. Inset panel of Fig. $3 \mathrm{~d}$ displays the cost comparison for both initial $\mathrm{pH}$ levels. The operating costs were similar at $\mathrm{pH} 3$ and $\mathrm{pH} 7\left(0.041 \pm 0.0004 € \mathrm{~g}^{-\mathrm{TOC}^{-1}}\right)$, since the slightly higher removal efficiency obtained at $\mathrm{pH} 3$ was counterbalanced by the absence of acidification at $\mathrm{pH}$ 7. However, in real applications a $\mathrm{pH}$ adjustment step will still be required after the treatment in order to neutralize the effluent, which will still lead to sludge management costs, since at $\mathrm{pH}$ value higher than $4, \mathrm{Fe}(\mathrm{III})$ precipitates into $\mathrm{Fe}(\mathrm{OH})_{3}$ with a solubility constant $\left(K_{\mathrm{s}}\right)$ equal to $2.79 \times 10^{-39}$ at $25^{\circ} \mathrm{C}$ (Bali et al., 2003).

\subsubsection{Photo-Fenton}

The efficiency of Fenton processes is known to increase in the presence of UV light, in the so-called photo-Fenton process (Oturan and Aaron, 2014), allowing the regeneration of $\mathrm{Fe}^{2+}$ (Ruppert et al., 1993) and the generation of additional radicals via the light-excitation of Fe-hydroxy complexes $\left(\mathrm{Fe}(\mathrm{OH})^{2+}\right)($ Benkelberg and Warneck, 1995). The effect of the same parameters as in dark Fenton was thus evaluated in UV-light conditions: the optimal $\mathrm{H}_{2} \mathrm{O}_{2}$ concentration, $\mathrm{Fe}^{2+}$ concentration and starting $\mathrm{pH}$ were $15 \mathrm{mM}$ (Fig. 4a), $0.7 \mathrm{mM}$ (Fig. 4b) and 3 (Fig. 4d), respectively. Higher $\mathrm{H}_{2} \mathrm{O}_{2}$ and $\mathrm{Fe}^{2+}$ concentrations increased the rate of parasitic reactions, as already stated for the Fenton process, and therefore a $\mathrm{Fe}^{2+} / \mathrm{H}_{2} \mathrm{O}_{2}$ ratio of 0.05 was deemed optimal. The best conditions led to $90 \%$ of phenol mineralization after 160 min (Figs. $4 \mathrm{a}-4 \mathrm{~b})$ and a $\mathrm{k}_{(1 \mathrm{st} \text { order })}$ value of $0.0716 \pm 0.0009 \mathrm{~min}^{-1}\left(\mathrm{R}^{2}>0.9821\right)$ (inset panel of Figs. 4a-4b). The associated operating cost was $0.13 \pm 0.008 €$ g-TOC ${ }^{-1}$ (Fig. $4 \mathrm{c}$ and inset panel of Fig. 4d). 
(a)

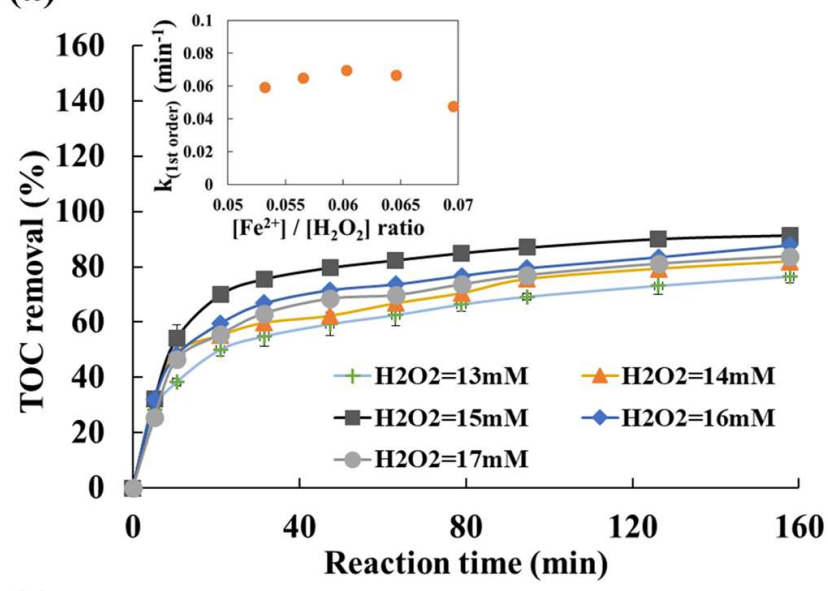

(c)

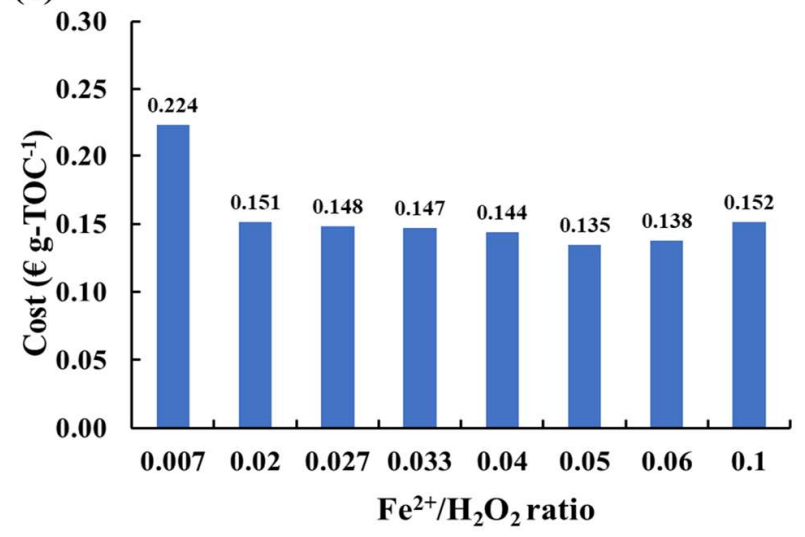

(b)

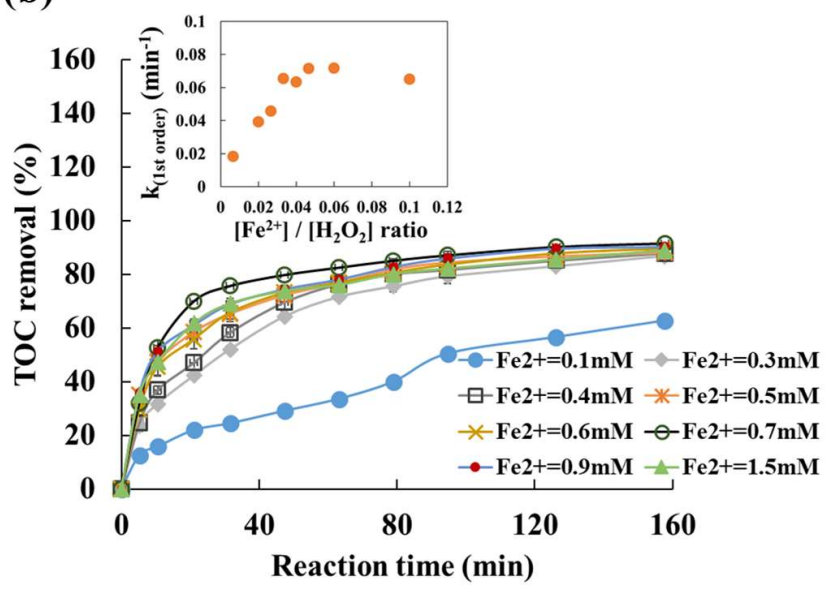

(d)

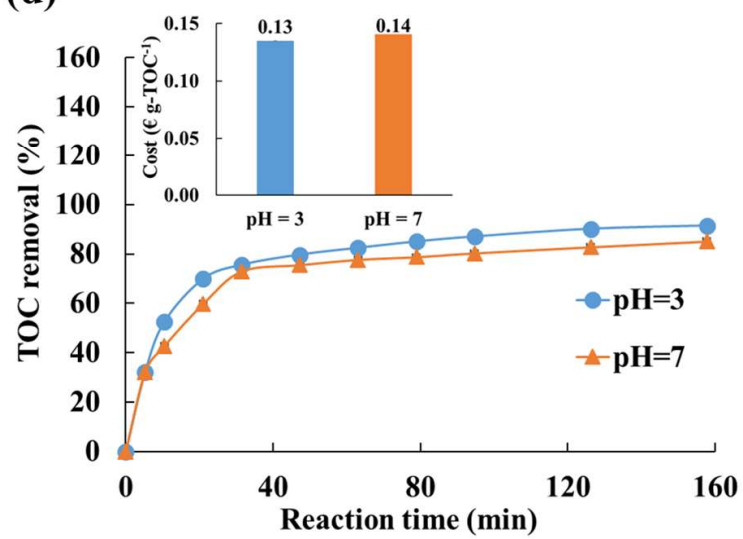

Fig. 4. Photo-Fenton process optimization: (a) TOC removal at different $\left[\mathrm{H}_{2} \mathrm{O}_{2}\right]$ (inset panel: $\mathrm{k}_{(1 \text { st order) }}$ ) at $\mathrm{pH} 3$ and $\left[\mathrm{Fe}^{2+}\right]=0.9 \mathrm{mM}$, (b) TOC removal at different $\left[\mathrm{Fe}^{2+}\right]$ (inset panel: $\mathrm{k}_{(1 \mathrm{st} \text { order) }}$ ) at $\mathrm{pH} 3$ and $\left[\mathrm{H}_{2} \mathrm{O}_{2}\right]=15 \mathrm{mM}$,

(c) cost efficiency at different $\mathrm{Fe}^{2+} / \mathrm{H}_{2} \mathrm{O}_{2}$ ratios after $160 \mathrm{~min}$, (d) TOC removal at different initial $\mathrm{pH}$ (inset panel: cost efficiency after $160 \mathrm{~min}$ ) at $\mathrm{Fe}^{2+} / \mathrm{H}_{2} \mathrm{O}_{2}$ ratio $=0.05$.

\subsubsection{Electro-Fenton}

Electro-Fenton, based on $\mathrm{H}_{2} \mathrm{O}_{2}$ electro-generation via the two-electron oxygen reduction on a carbon-based cathode (Mousset et al., 2016b) was tested next in paired electrocatalysis, combined with a high $\mathrm{O}_{2}$ evolution overpotential BDD anode (Brillas, 2014; Nidheesh et al., 2019). First, the effect of $\mathrm{Fe}^{2+}$ concentration $(0.05 \mathrm{mM}$ to $0.3 \mathrm{mM}$ ), acting as a catalyst for the Fenton's reaction, was investigated and the results highlighted the optimal $\left[\mathrm{Fe}^{2+}\right]$ of $0.1 \mathrm{mM}$, yielding $76 \%$ phenol mineralization in $160 \mathrm{~min}$ (Fig. 5a), while higher $\mathrm{Fe}^{2+}$ concentrations 
promoted secondary reactions (Mousset et al., 2016a). For every concentration, the mineralization followed a linear trend because the electro-oxidation reaction of organic compounds at the BDD surface was the rate-limiting step instead of mass transfer limitations (Mousset et al., 2019; Panizza et al., 2001). Consequently, the phenol mineralization kinetics followed zero order kinetics $\left(\mathrm{k}_{(0 \text { order })}\right)$ during the first hours of treatment $\left(\mathrm{R}^{2}>0.9855\right)$, as already demonstrated in the literature with medium to highly concentrated solutions (Mousset et al., 2019; Panizza et al., 2001). The optimal rate constant for phenol mineralization was obtained at the optimal concentration of 0.1 $\mathrm{mM}$ of $\mathrm{Fe}^{2+}\left(\mathrm{k}_{(0 \text { order })}=0.0458 \pm 0.0002 \mathrm{mg}-\mathrm{C} \mathrm{L}^{-1} \mathrm{~h}^{-1}\right.$, cf. inset panel of Fig. 5a). This concentration also proved to be the most cost-effective $\left(0.031 \pm 0.0005 € \mathrm{~g}^{-\mathrm{TOC}^{-1}}\right.$, cf. Fig. $\left.5 \mathrm{~b}\right)$.

The current density $(\mathrm{J})$ was then optimized at the optimal $\mathrm{Fe}^{2+}$ concentration of $0.1 \mathrm{mM}$ and the results are shown in Fig. 5c. The optimal current density was $1.25 \mathrm{~mA} \mathrm{~cm}{ }^{-2}$, yielding $76 \%$ of phenol mineralization in $160 \mathrm{~min}\left(\mathrm{k}_{(0}\right.$ order) $=0.0458 \pm 0.0002 \mathrm{mg}-\mathrm{C} \mathrm{L}^{-1} \mathrm{~h}^{-1}$, cf inset panel of Fig. $5 \mathrm{c}$ ) at a cost of $0.031 \pm 0.0005 € \mathrm{~g}_{\text {-TOC }}{ }^{-1}$ (Fig. $5 \mathrm{~d}$ ). Higher current densities favored the oxygen evolution reaction over the production of ${ }^{\circ} \mathrm{OH}$ (Panizza and Cerisola, 2009). Unsurprisingly, the best starting pH was 3 (Fig. 5e, inset panel of Fig. 5e and Fig. 5f), in agreement with our previous observations on other Fenton-based processes. Hence, the optimal operating conditions for the paired electro-Fenton process consisted of $0.1 \mathrm{mM}$ of $\mathrm{Fe}^{2+}$, a current density of $1.25 \mathrm{~mA} \mathrm{~cm}{ }^{-2}$ and a $\mathrm{pH}$ of 3 . 
(a)

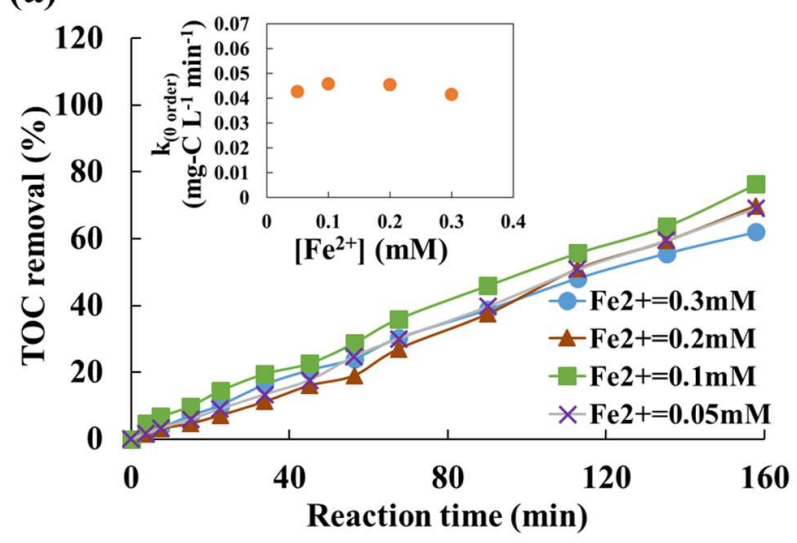

(c)

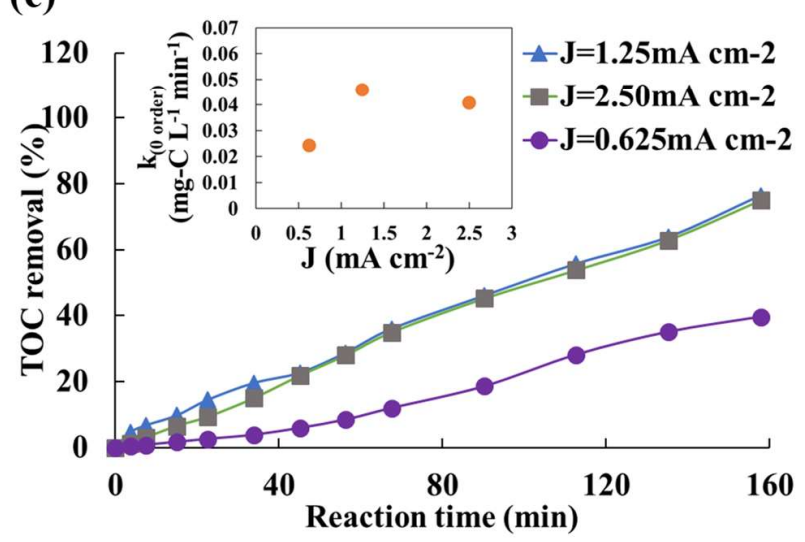

(e)

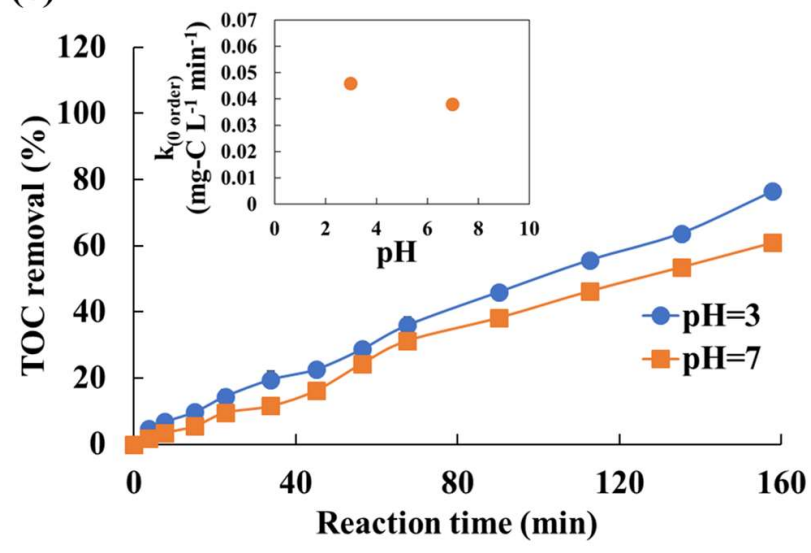

(b)

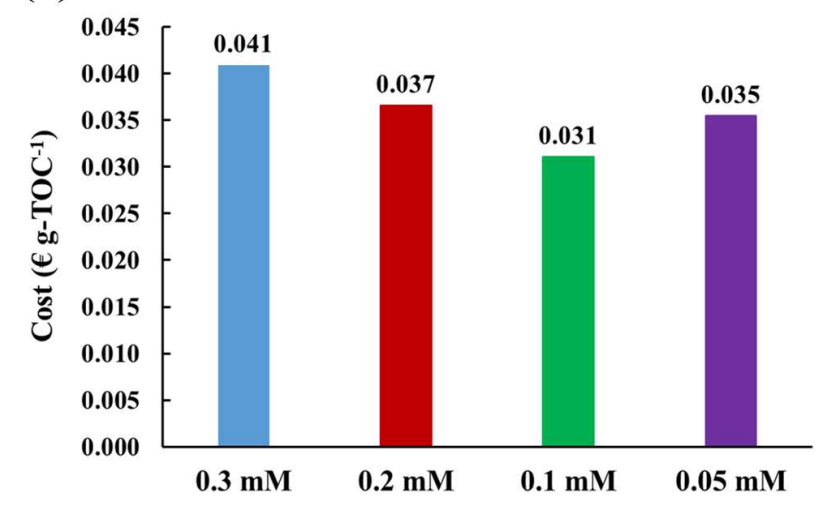

(d)

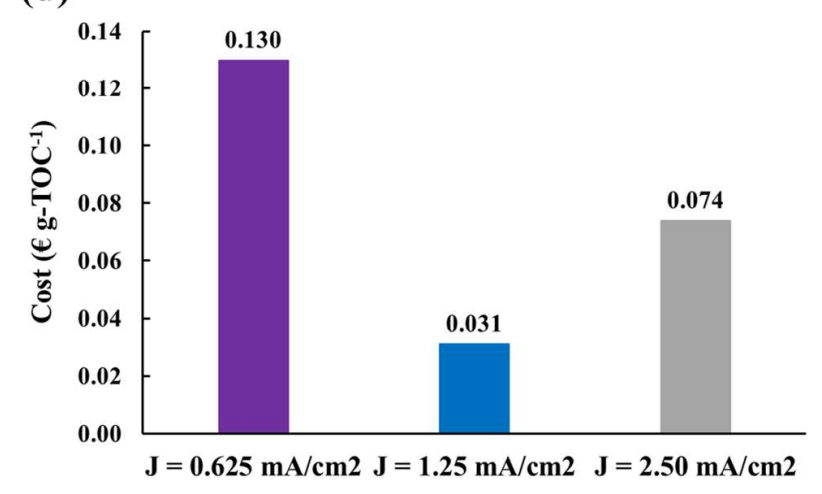

(f)

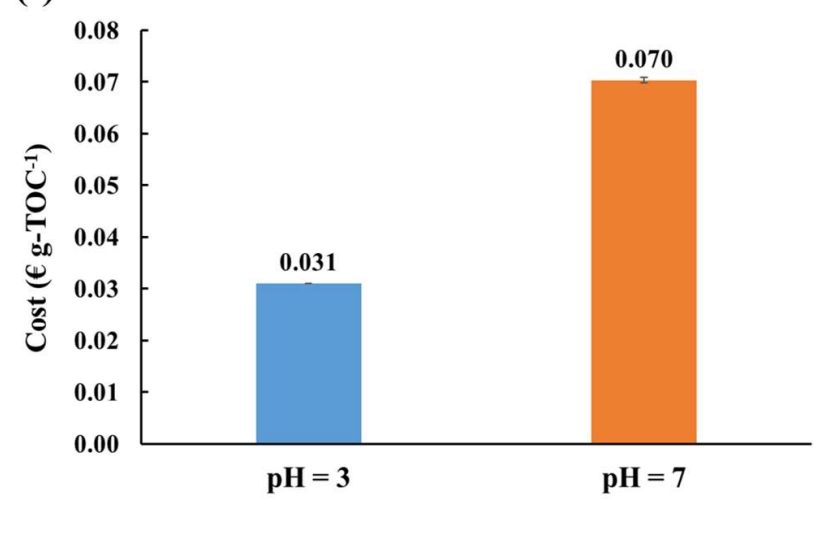

Fig. 5. Electro-Fenton process optimization: (a) TOC removal at different $\left[\mathrm{Fe}^{2+}\right]$ (inset panel: $\mathrm{k}_{(0 \text { order })}$ ) at $\mathrm{pH} 3$ and $\mathrm{J}=1.25 \mathrm{~mA} \mathrm{~cm}{ }^{-2}$, (b) cost efficiency at different $\left[\mathrm{Fe}^{2+}\right]$ after $160 \mathrm{~min}$, (c) TOC removal at different $\mathrm{J}$ (inset panel: $\left.\mathrm{k}_{(0 \text { order })}\right)$ at $\mathrm{pH} 3$ and $\left[\mathrm{Fe}^{2+}\right]=0.1 \mathrm{mM}$, (d) cost efficiency at different $\mathrm{J}$ after $160 \mathrm{~min}$, (e) TOC removal at different initial $\mathrm{pH}$ (inset panel: $\mathrm{k}_{(0 \text { order })}$ ) at $\left[\mathrm{Fe}^{2+}\right]=0.1 \mathrm{mM}$ and $\mathrm{J}=1.25 \mathrm{~mA} \mathrm{~cm}{ }^{-2}$, (f) cost efficiency at different initial $\mathrm{pH}$ after $160 \mathrm{~min}$. 


\subsubsection{Photoelectro-Fenton}

Similarly as for chemical Fenton, UV-light was added to electro-Fenton to boost the production of ${ }^{\circ} \mathrm{OH}$ (Brillas et al., 2009; Sun and Pignatello, 1993) and the regeneration of $\mathrm{Fe}^{2+}$ (Ruppert et al., 1993). The optimal $\mathrm{Fe}^{2+}$ concentration, current density and starting $\mathrm{pH}$ in the resulting photoelectro-Fenton process were $0.1 \mathrm{mM}$ (Figs. 6a-6b), $1.25 \mathrm{~mA} \mathrm{~cm}^{-2}$ (Figs. 6c-6d) and 3 (Figs. 6e-6f), respectively, yielding 88\% of phenol mineralization in 160 $\min$ (Figs. 6a, 6c, 6e), a $\mathrm{k}_{(0 \text { order) }}$ value of $0.053 \pm 0.0003 \mathrm{mg}-\mathrm{C} \mathrm{L}^{-1} \mathrm{~h}^{-1}\left(\mathrm{R}^{2}>0.9856\right)$ (inset panel of Figs. 6a, 6c, 6e) and a cost of $0.18 \pm 0.007 €$ g-TOC $^{-1}$ (Figs. 6b, 6d, 6f). Higher current densities increased the rate of secondary reactions that hampered the ${ }^{\circ} \mathrm{OH}$ production, as already stated for the electro-Fenton experiments. 
(a)

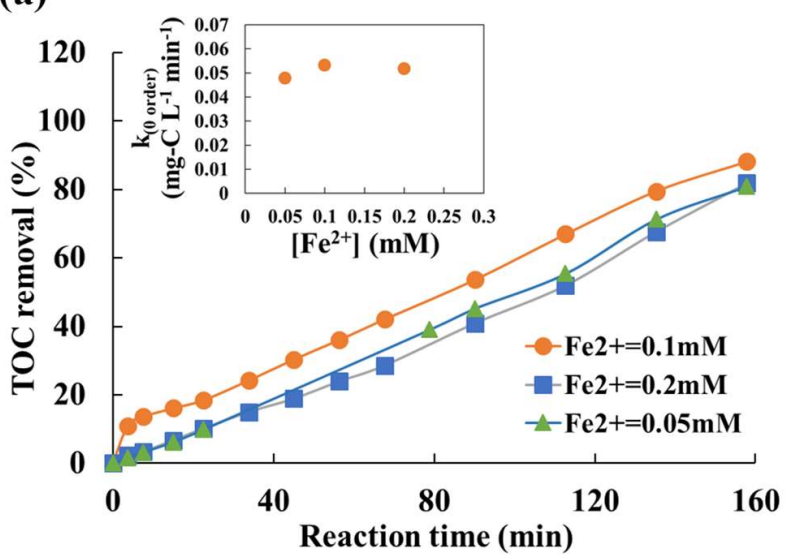

(c)

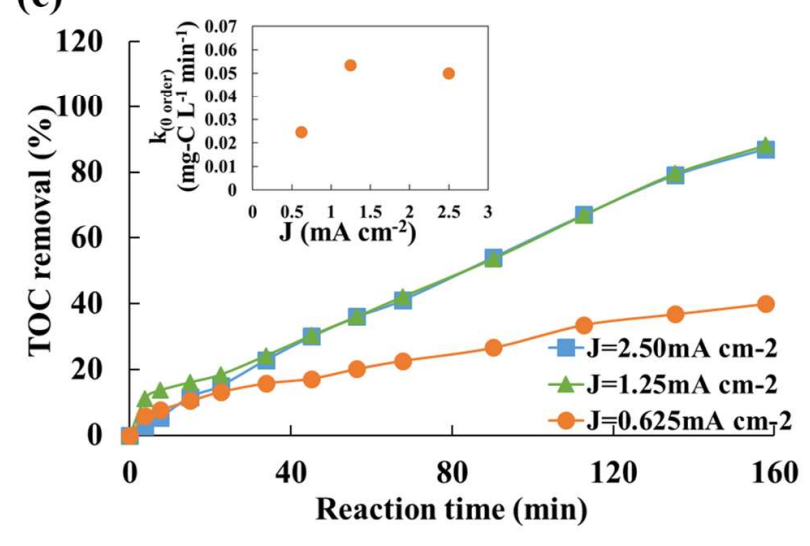

(e)

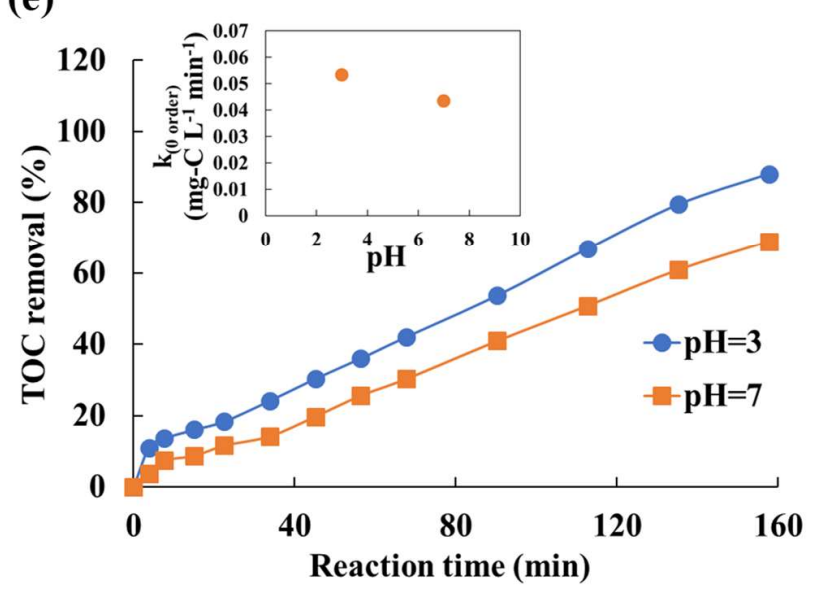

(b)

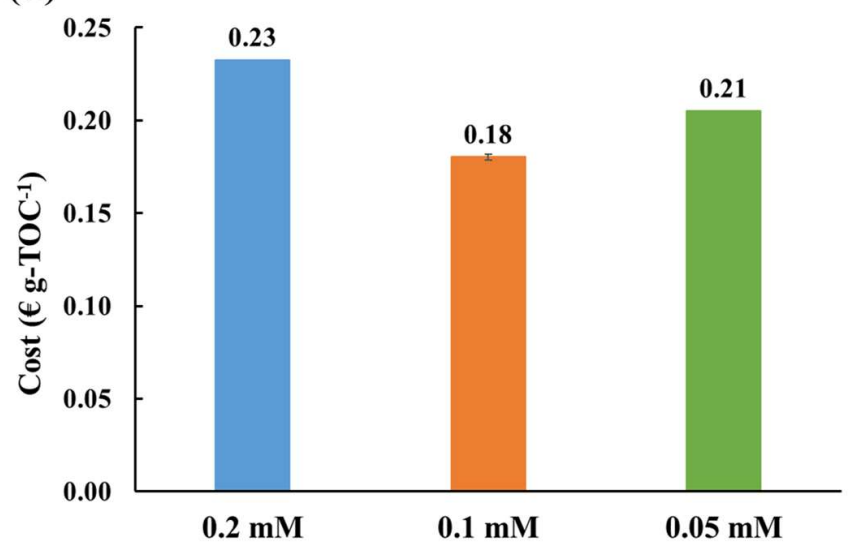

(d)

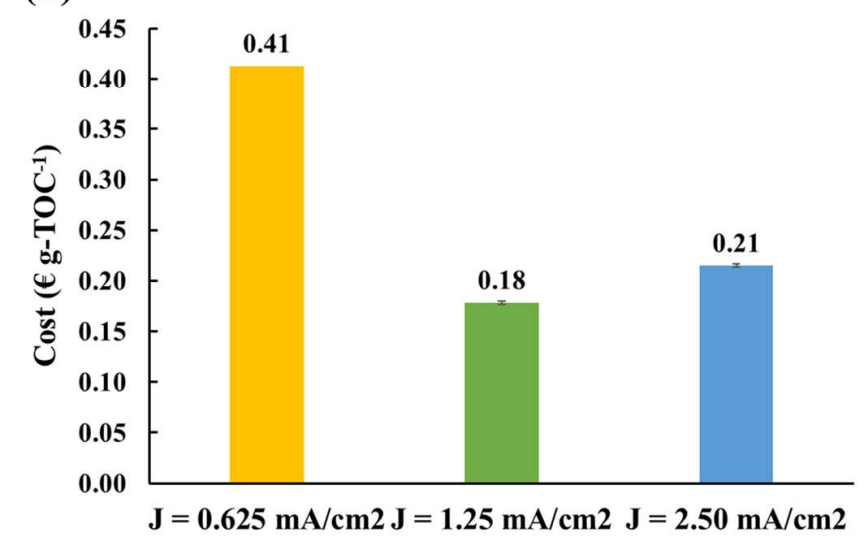

(f)

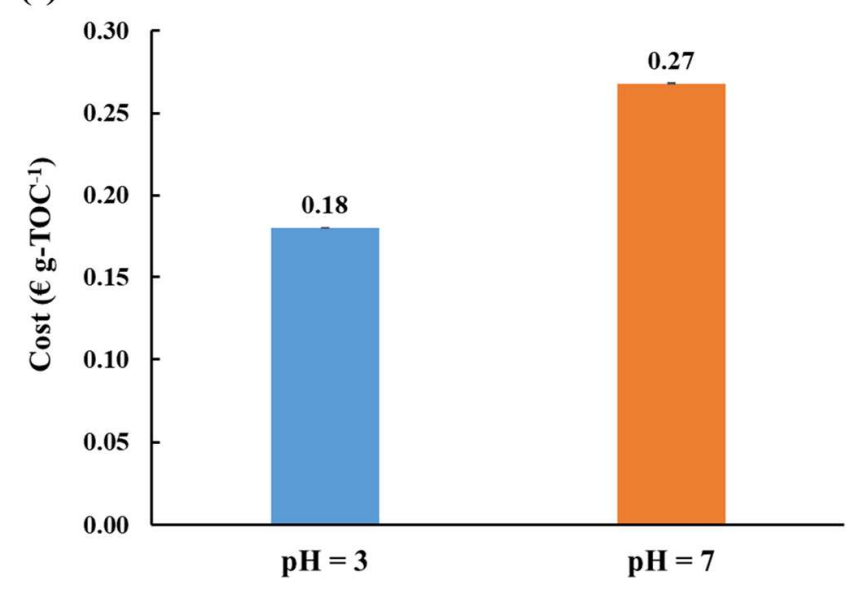

Fig. 6. Photoelectro-Fenton process optimization: (a) TOC removal at different $\left[\mathrm{Fe}^{2+}\right]$ (inset panel: $\mathrm{k}_{(0 \text { order })}$ ) at $\mathrm{pH}$ 3 and $\mathrm{J}=1.25 \mathrm{~mA} \mathrm{~cm}{ }^{-2}$, (b) cost efficiency at different $\left[\mathrm{Fe}^{2+}\right]$ after $160 \mathrm{~min}$, (c) TOC removal at different $\mathrm{J}$ (inset panel: $\mathrm{k}_{(0 \text { order })}$ ) at $\mathrm{pH} 3$ and $\left[\mathrm{Fe}^{2+}\right]=0.1 \mathrm{mM}$, (d) cost efficiency at different $\mathrm{J}$ after $160 \mathrm{~min}$, (e) TOC removal at different initial $\mathrm{pH}$ (inset panel: $\mathrm{k}_{(0 \text { order })}$ ) at $\left[\mathrm{Fe}^{2+}\right]=0.1 \mathrm{mM}$ and $\mathrm{J}=1.25 \mathrm{~mA} \mathrm{~cm}{ }^{-2}$, (f) cost efficiency at different initial $\mathrm{pH}$ after $160 \mathrm{~min}$. 


\subsection{Techno-economic analysis}

\subsubsection{Performance comparison of six AOPs for phenol mineralization}

Cost comparison is an essential component of benchmarking AOPs against one another, depending upon their foreseen application, e.g., as a pre- or partial treatment (i.e. $50 \%$ or $75 \%$ of mineralization) or to achieve complete mineralization (> 99\%). To that effect, the cost of every AOP in its optimal conditions and normalized by the treated volume and the mass of TOC removed (expressed in $€ \mathrm{~m}^{-3} \mathrm{~g}-\mathrm{TOC}^{-1}$ (Lucas et al., 2010), taking into account the sludge management, chemical use and electrical power costs) is plotted in Fig. 7, for different targets of mineralization. $\mathrm{UV} / \mathrm{H}_{2} \mathrm{O}_{2}$ was the least effective AOP, unable to reach more than $17 \%$ of phenol mineralization after 160 min of treatment, a low performance that corroborates former studies (Bali et al., 2003). UV/ $\mathrm{H}_{2} \mathrm{O}_{2}$ was therefore excluded from this cost-comparison analysis. For the other techniques, the performance at $50 \%$ of mineralization ranked as follows (Fig. 7a): Fenton $\left(102 € \mathrm{~m}^{-3} \mathrm{~g}^{-\mathrm{TOC}^{-1}}\right)>$ electro-Fenton $\left(108 € \mathrm{~m}^{-3} \mathrm{~g}^{-\mathrm{TOC}^{-1}}\right)>$ photo-Fenton $\left(161 € \mathrm{~m}^{-3} \mathrm{~g}\right.$-TOC $\left.{ }^{-1}\right)>$ photoelectro-Fenton $\left(340 € \mathrm{~m}^{-3} \mathrm{~g}-\mathrm{TOC}^{-1}\right)>$ ozonation $\left(966 € \mathrm{~m}^{-3} \mathrm{~g}^{-T_{O C}}{ }^{-1}\right)$. Fenton was thus the most competitive at $50 \%$ of mineralization, followed closely by electro-Fenton that then became more cost-effective at higher mineralization yields (Fig. 7a): indeed, at 75\%, the ranking became electroFenton $>$ photo-Fenton $>$ photoelectro-Fenton $>$ Fenton $>$ ozonation and at 99\%, electro-Fenton $>$ photoelectroFenton $>$ photo-Fenton $>$ Fenton $>$ ozonation. The overall costs for ozonation were always higher than for Fentonbased processes, notwithstanding the mineralization target. Ozonation was therefore less competitive which confirms the findings of Canizares et al. (Cañizares et al., 2009). Photoelectro-Fenton was costlier than photoFenton at $50 \%$ and $75 \%$ of mineralization, while it was more competitive at $99 \%$ of mineralization. In this latter condition, the gain in TOC removal was sufficient to counterbalance the higher energy requirements for electrolysis. Still, UV-based Fenton processes were costlier than dark electro-Fenton, due to the energy requirement from the UV lamp. This shows the importance to study the potential of solar irradiation instead of artificial UV light to increase the competitiveness of photo-processes (Flox et al., 2007). In addition, UV-based AOPs present other significant drawbacks, depending upon the characteristics of the effluent to be treated, as color, 
turbidity and interfering compounds absorbing UV irradiation can considerably decrease the effectiveness of lightbased AOPs in real applications (Rodríguez, 2003).

For all processes, the overall cost efficiency decreased with increasing mineralization targets, but it is worthy of note that electro-Fenton was much less impacted by this trend. The catalytic behavior of the iron source for the Fenton's reaction allowed minimizing the chemical costs, rendering its cost performance barely dependent upon the mineralization target. This was verified by the zero-order kinetics observed, with faradaic yields close to one (Panizza and Cerisola, 2009). In contrast, the low quantum yields of UV-based AOPs (approx. 0.12 for phenol (Okamoto et al., 1985)), resulted in increasing costs to reach higher mineralization targets. Photoelectro-Fenton remained proportionally less impacted than photo-Fenton, by benefiting from the high faradaic yield of electrolysis, while the low solubility of ozone (Oturan and Aaron, 2014) resulted in excessive amounts of gas supplied to the process, which increased the costs. Finally, the absence of regeneration of iron in chemical Fenton considerably increased waste reactions at higher mineralization targets.

The cost-distribution of the different AOPs at different mineralization targets is displayed in Figs. 7b-7d. It can be seen that chemicals always represented the primary source of expense for chemical Fenton, but were overtaken by electricity for ozonation, electro-Fenton, photo-Fenton and photoelectro-Fenton, regardless of the mineralization yield. For instance, for a target of $75 \%$ of mineralization, the chemicals represented $99.4 \%$ of the overall costs for Fenton, while the contribution of electricity accounted for $97.9 \%, 88.3 \%, 77.9 \%$ and $64.2 \%$ for ozonation, photoelectro-Fenton, photo-Fenton and electro-Fenton, respectively (Fig. 7b). An exception was noted for electroFenton at $50 \%$ of mineralization, in which chemicals cost represented around half of the overall costs $(49.9 \%)$. The UV-based Fenton processes required higher electrical costs in proportion, due to the UV lamp, and the relative proportion of power over chemical costs increased with the mineralization target for ozonation, photo-Fenton, electro-Fenton and photoelectro-Fenton (Figs. 7b-7d), in relation with to the increased treatment time. In addition, the sludge management cost proportion was always higher for Fenton than for photo-Fenton, electro-Fenton and photoelectro-Fenton, as a result of the constant addition of $\mathrm{Fe}^{2+}$ in the absence of its regeneration, yielding more ferric sludge at the end of the treatment. In terms of sludge management cost, the ranking was as follows: 
photoelectro-Fenton $<$ electro-Fenton $<$ photo-Fenton $<$ Fenton, directly linked to the regeneration rate of $\mathrm{Fe}^{2+}$ that was the highest in photoelectro-Fenton followed by electro-Fenton. Nevertheless, the sludge cost remained negligible regardless of the Fenton-based process considered, implying that this parameter will not make a significant cost difference (Figs. 7b-7d). This is an interesting feature, because many recent works have been focusing on trying to limit the ferric sludge production in Fenton-based processes by implementing heterogeneous Fenton systems (Ganiyu et al., 2018). Yet, the main advantage of heterogeneous processes would arguably be more in terms of their impact on chemical cost reduction by avoiding the need to adjust the $\mathrm{pH}$ to 3 (Deng et al., 2018). Still, it is important to note that the volume of sludge represented around $15 \%$ of the treated wastewater in the Fenton process applied in a previous study (Cañizares et al., 2009), which would result in non-negligible sludge management costs. In that study, the concentration of $\mathrm{Fe}^{2+}$ was 4 to 180 times higher than in this work, depending upon the pollutant treated, which led to drastically higher generation of ferric hydroxide sludge. Moreover, the authors considered the wet sludge production (expressed in $\mathrm{m}^{3}$ sludge per $\mathrm{m}^{3}$ of treated wastewater) in their cost calculation (Cañizares et al., 2009), while the dehydrated sludge is taken into account in our work. Another study reported that the volume of sludge produced by Fenton $\left(0.267 \mathrm{~m}^{3}\right.$ sludge $/ \mathrm{m}^{3}$ wastewater $)$ only comprised $2.5 \%$ $(\mathrm{w} / \mathrm{w})$ of TSS, which further explains the strong reduction of sludge amount by considering the dehydrated sludge as compared to the wet sludge (Benatti and Tavares, 2012). Moreover, the quantity of sludge could prove higher with real wastewater, considering that other species can co-precipitate, such as metallic compounds initially present in solution (Benatti and Tavares, 2012).

In conclusion to this section, the Fenton process proved a reasonable option as a pre-treatment if mineralization lower than $50 \%$ is required, while electro-Fenton is always a good candidate, notwithstanding the target (recommended both for pre-treatment or as a stand-alone technology for total mineralization). Of course, these cost estimates are based on laboratory-scale experiments and omit additional operational costs inherent to all AOPs (e.g. power cost from pumps) as well as equipment costs that would need to be factored in at the industrial scale. The equipment cost in particular may vary with the size of the plant as previously shown for advanced electrooxidation, Fenton and ozonation (Cañizares et al., 2009). In addition, the impact of the matrix of real effluents 
would also need to be taken into account to refine our numbers for specific applications. Since the efficiency of all AOPs rely on the reactivity of ${ }^{\circ} \mathrm{OH}$ with targeted compounds in wastewater, arguably comparable matrix effects could be expected, notwithstanding the type of AOP implemented. Thus, ${ }^{\circ} \mathrm{OH}$ exposure is typically estimated based on the kinetics of degradation/mineralization of the targeted compounds and on the competing reactions with ${ }^{\circ} \mathrm{OH}$ scavengers (e.g., carbonate, bicarbonate, nitrite, organic matter) that are often present in water matrices (Miklos et al., 2018). Of course, some differences could be expected with real matrices, such as the presence of turbidity that can affect UV-based processes (as mentioned earlier), while unwanted by-products (e.g., $\mathrm{BrO}_{3}{ }^{-}$with $\mathrm{O}_{3}$ or $\mathrm{ClO}_{3}{ }^{-}$with electrochemical treatments) could also be formed depending upon the ions present in the matrix (Br-, Cl-, etc.) (Bergmann et al., 2014; Garcia-Rodriguez et al., 2020; Lee et al., 2016; Mousset et al., 2018b; Mousset et al., 2020). 


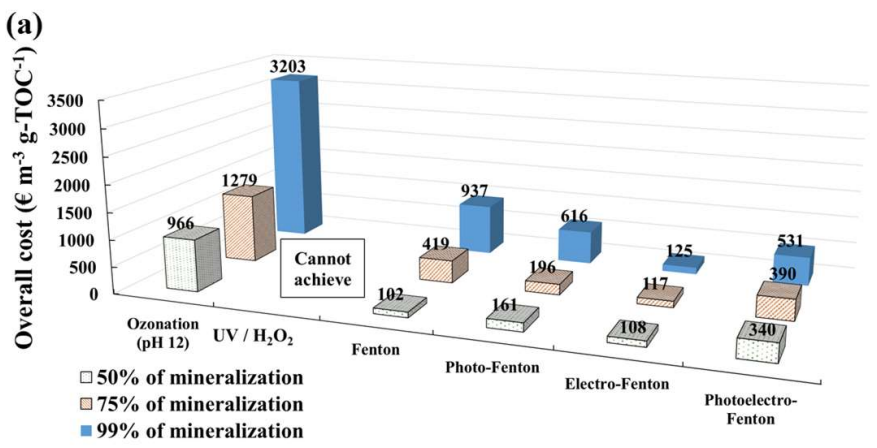

(b)

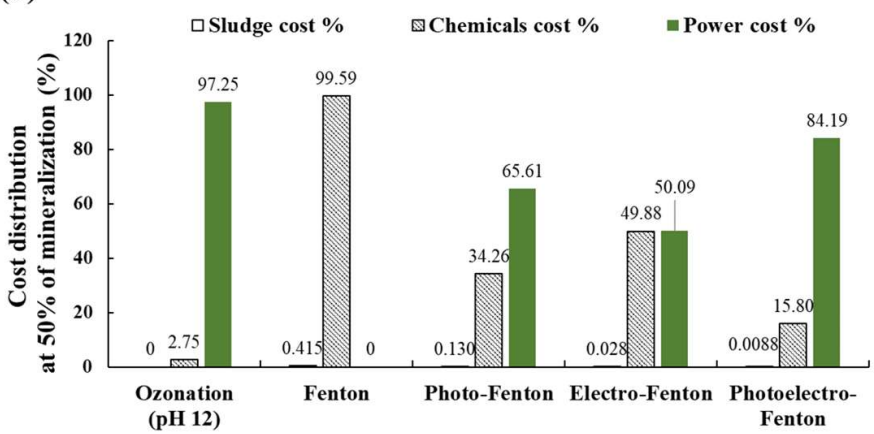

(c)

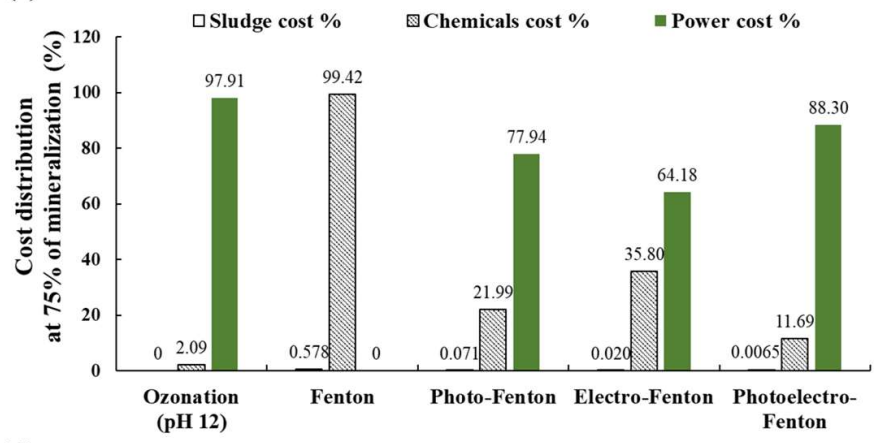

(d)

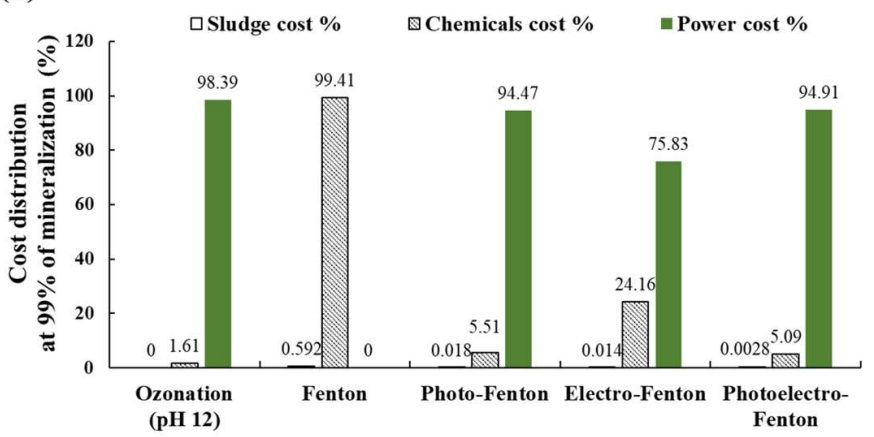

Fig. 7. AOPs cost efficiency comparison at different phenol mineralization yield: (a) overall cost, (b) costs distribution at $50 \%$ of mineralization, (c) costs distribution at $75 \%$ of mineralization, (d) costs distribution at $99 \%$ of mineralization. 
3.2.2. A new criterion to enable systematic AOP cost-performance comparison: the accumulated oxygen-equivalent chemical-oxidation dose (AOCD)

The need to develop criteria for suitable comparison between AOPs is important for evaluating the best available technologies as defined by the European Commission (Rizzo et al., 2020). Canizares et al. (Cañizares et al., 2009) have previously proposed the $\mathrm{OCC}\left(\mathrm{kg}_{-} \mathrm{O}_{2} \mathrm{~m}^{-3}\right)$ as a parameter to compare advanced electro-oxidation with Fenton and ozonation. Here, a new parameter is proposed, namely the AOCD $\left(\mathrm{kg}-\mathrm{O}_{2}\right)$, to compare the different AOPs used in this work. The difference and arguably advantage of AOCD compared to OCC is that it takes into account the accumulation of the dose normalized to the treatment time and it is more comprehensive by encompassing the photo-based processes as well as other important parameters, i.e., current density, irradiance, wavelength, active surface of the electrodes and lamp, distance of the lamp, faradaic and quantum yields, number of electrons exchanged, residence time. The AOCD for each process $i$ is proposed to be estimated from the following general equation (Eq. 1):

$\operatorname{AOCD}_{i}\left(\mathrm{~kg}-\mathrm{O}_{2}\right)=\int_{0}^{\tau} O C D_{i}\left(k g-O_{2} h^{-1}\right) d \tau$

where the oxygen-equivalent chemical-oxidation dose (OCD) equations for each process are fully developed in Text S2 and Table S1; a summarized form is presented below for each AOP: ozonation (Eq. 2), Fenton (Eq. 3), UV/ $\mathrm{H}_{2} \mathrm{O}_{2}$ and photo-Fenton (Eq. 4), electro-Fenton (Eq. 5) and photoelectro-Fenton (Eq. 6).

$$
\begin{aligned}
& O C D_{\text {Ozone }}\left(k g-O_{2} h^{-1}\right)=1.000 \times D_{O_{3}}\left(k g-O_{3} h^{-1}\right) \\
& O C D_{\text {Fenton }}\left(k g-O_{2} h^{-1}\right)=0.471 \times D_{H_{2} O_{2}}\left(k g-H_{2} O_{2} h^{-1}\right) \\
& O C D_{H_{2} O_{2} \text { photolysis or photo-Fenton }}\left(k g-O_{2} h^{-1}\right)=0.471 \times D_{H_{2} O_{2}}\left(k g-H_{2} O_{2} h^{-1}\right)+0.067 \times I_{\lambda}\left(k J m^{-2} h^{-1}\right) \times \frac{\lambda(m)}{\Phi_{\lambda}} \times \\
& S_{\text {lamp }}\left(m^{2}\right) \\
& \text { with } S_{\text {lamp }}\left(m^{2}\right)=\frac{2 D L+\left(4 D^{2}+L^{2}\right) \arctan \left(\frac{L}{2 D}\right)}{D L\left(4 D^{2}+L^{2}\right) \pi^{2}} \\
& O C D_{\text {Electro-Fenton }}\left(k g-O_{2} h^{-1}\right)=0.298 \times J\left(k A m^{-2}\right) \times \frac{\sum_{i} n\left(e^{-}\right)_{i}}{\Phi_{e^{-}}} \times S_{\text {electrode }}\left(m^{2}\right)
\end{aligned}
$$




$$
\begin{aligned}
& \text { OCD } D_{\text {photoelectro-Fenton }}\left(\mathrm{kg}-\mathrm{O}_{2} \mathrm{~h}^{-1}\right)=0.298 \times J\left(\mathrm{kA} \mathrm{m}^{-2}\right) \times \frac{\sum_{i} n\left(e^{-}\right) i}{\Phi_{e^{-}}} \times S_{\text {electrode }}\left(\mathrm{m}^{2}\right)+0.067 \times I_{\lambda}\left(\mathrm{kJ} \mathrm{m}^{-2} \mathrm{~h}^{-1}\right) \times \\
& \frac{\lambda(\mathrm{m})}{\Phi_{\lambda}} \times S_{\text {lamp }}\left(\mathrm{m}^{2}\right)
\end{aligned}
$$

where $D_{O_{3}}$ is the ozone dose $\left(\mathrm{kg}-\mathrm{O}_{3} \mathrm{~h}^{-1}\right), D_{\mathrm{H}_{2} \mathrm{O}_{2}}$ is the $\mathrm{H}_{2} \mathrm{O}_{2}$ dose $\left(\mathrm{kg}-\mathrm{H}_{2} \mathrm{O}_{2} \mathrm{~h}^{-1}\right), I_{\lambda}$ is the irradiance $\left(\mathrm{kJ} \mathrm{m}^{-2} \mathrm{~h}^{-1}\right)$ at a specific wavelength $\lambda(\mathrm{m})$, considering the quantum yield $\left(\Phi_{\lambda}\right)$ for the target compound degradation $\left(\Phi_{\lambda}=0.12\right.$ for phenol; (Okamoto et al., 1985)) and considering the active surface of the lamp $S_{\text {lamp }}\left(\mathrm{m}^{2}\right), J$ is the current density $\left(\mathrm{kA} \mathrm{m}^{-2}\right)$ considering the geometric surface $\left(S_{\text {electrode }}\left(\mathrm{m}^{2}\right)\right)$ of the working electrode (i.e., anode for anodic oxidation, cathode for electro-Fenton and both electrodes for electro-Fenton paired with anodic oxidation), $n\left(\mathrm{e}^{-}\right)$is the number of electrons exchanged for electrogenerating species $i$ (i.e. $\mathrm{H}_{2} \mathrm{O}_{2}$ at cathode and ${ }^{\circ} \mathrm{OH}$ at anode) $\left(\sum_{i} n\left(e^{-}\right)_{i}=3\right.$ in electro-Fenton paired with anodic oxidation), $\Phi_{e^{-}}$is the faradaic yield towards the target compound degradation ( $\Phi_{e^{-}}=1$ in this work considering the zero order kinetic model; (Panizza and Cerisola, 2009)), $\tau$ is the residence time of the solution to treat (h), $V$ is the volume of the solution to treat $\left(\mathrm{m}^{3}\right), D$ is the distance from the lamp to the solution to treat $\left(\mathrm{m}^{2}\right)$ and $L$ is the length of the lamp $\left(\mathrm{m}^{2}\right)$.

Following the protocol described above, the TOC decay percentages were plotted against the AOCD for each AOP (Fig. 8). Logically, the AOCD increased with the mineralization yields, regardless of the AOP considered (Fig. 8). The required oxidant dose in terms of AOCD was ranked as follows (from the lowest to the highest dose): electroFenton $<$ photoelectro-Fenton $<$ Fenton $<$ photo-Fenton $<$ ozonation $\left(\mathrm{pH} \mathrm{12)}<\mathrm{UV} / \mathrm{H}_{2} \mathrm{O}_{2}\right.$. The photo-based processes always showed higher AOCD compared to their dark counterpart, owing to their lower quantum yield. The accumulated dose for ozonation was higher than that of the other AOPs, except for $\mathrm{UV} / \mathrm{H}_{2} \mathrm{O}_{2}$. This is consistent with previous data that showed higher OCC values with ozone compared to Fenton and anodic oxidation (Cañizares et al., 2009). Electro-Fenton always required the lowest dose for all mineralization targets, from 0.0004 $\mathrm{kg}-\mathrm{O}_{2}$ at $50 \%$ to $0.0012 \mathrm{~kg}-\mathrm{O}_{2}$ at $99 \%$. These results showcase electro-Fenton as the most versatile option when 
compared to other AOPs for a large range of applications, i.e. suitable as a pre-treatment or for total mineralization. This is consistent with the cost efficiency comparison performed in section 3.2.1 and also with others (Sirés et al., 2014).

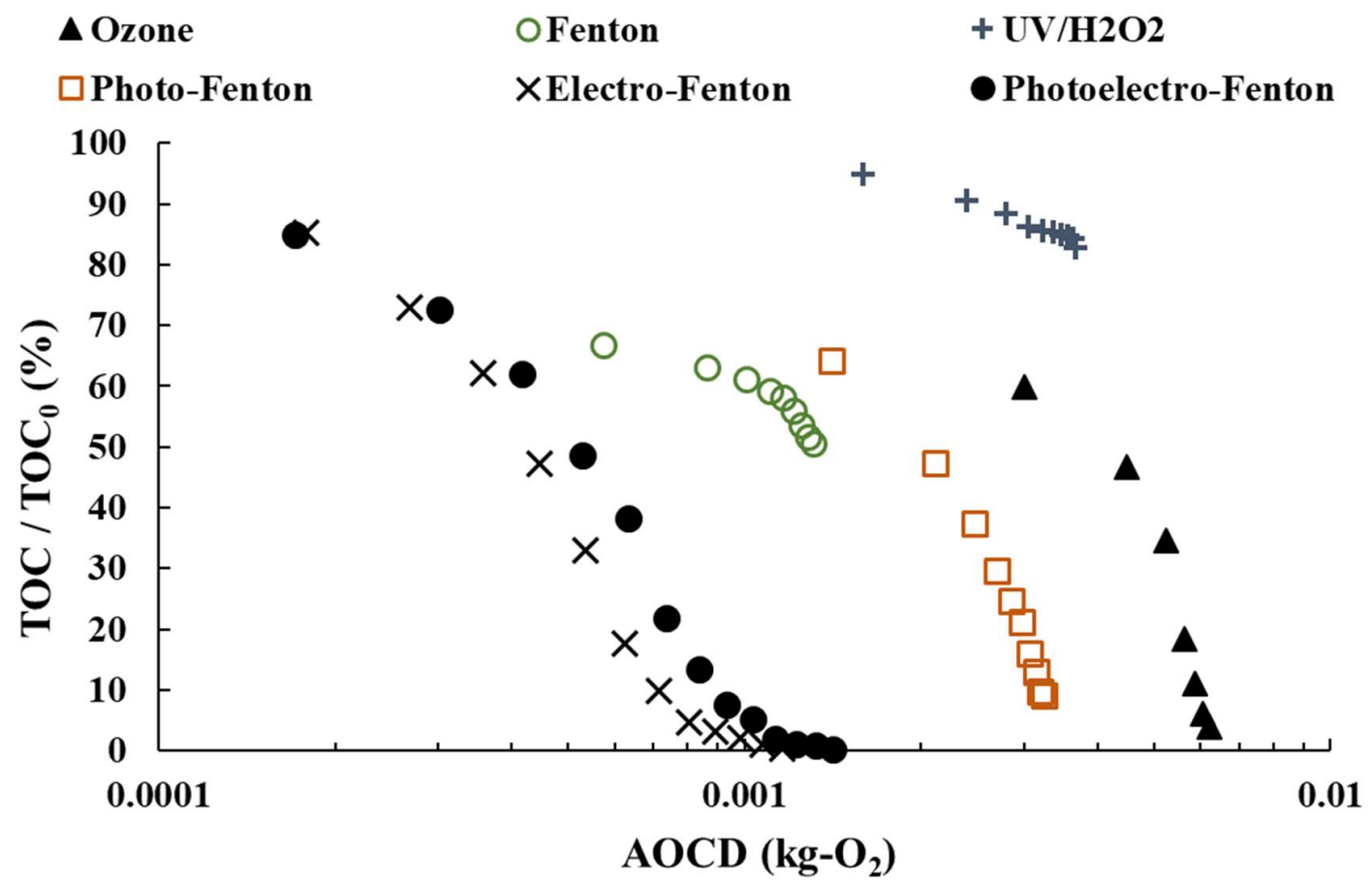

Fig. 8. TOC decay percentage as function of accumulated oxygen-equivalent chemical-oxidation dose (AOCD) for AOPs comparison.

\section{Conclusions}

In this work, a systematic approach was proposed to compare six different kinds of AOPs consisting of ozonation, Fenton, $\mathrm{H}_{2} \mathrm{O}_{2}$ photolysis, photo-Fenton, electro-Fenton and photoelectro-Fenton, taking into account their operating cost efficiency (power, chemicals and sludge management costs) for their preliminary optimization. Moreover, a new criterion that allows AOP comparison was proposed, namely the AOCD, which improves on the literature by covering more AOPs and including more cost criteria (e.g., active surface of the electrodes and lamp). 
The main findings obtained at laboratory scale in batch mode and with artificial wastewater containing phenol as model pollutant are summarized below:

- $\mathrm{UV} / \mathrm{H}_{2} \mathrm{O}_{2}$ displayed the lowest mineralization efficiency, while among the Fenton-based AOPs, electro-Fenton (paired with anodic oxidation) depicted the best cost performance (108-125€ $\left.\mathrm{m}^{-3} \mathrm{~g}-\mathrm{TOC}^{-1}\right)$, notwithstanding the mineralization targets $(50 \%, 75 \%$ and $99 \%)$.

- Ozonation was less cost effective than the Fenton-based AOPs.

- Fenton proved competitive when the goal was to reach $50 \%$ of mineralization and thus proved a suitable pretreatment.

- Electro-Fenton was the most versatile process in the tested conditions, covering pre-treatment up to total mineralization.

Further studies will be required in continuous mode at pilot and industrial scale in real wastewater matrices in order to validate the suitability of the AOCD criterion and of the AOP comparison.

\section{Acknowledgements}

The authors would like to thanks the National University of Singapore (NUS) for funding this study through the grant WBS R302000111133. 


\section{References}

A. Sychev, V.I., 1995. Iron compounds and the mechanisms of the homogeneous catalysis of the activation of O2 and $\mathrm{H} 2 \mathrm{O} 2$ and of the oxidaiton of organic substrates. Russ. Chem. Rev. 65, 1105-1129.

Azevedo, E.B., Tôrres, a. R., Aquino Neto, F.R., Dezotti, M., 2009. TiO2-Photocatalyzed degradation of phenol in saline media in an annular reactor: Hydrodynamics, lumped kinetics, intermediates, and acute toxicity. Brazilian J. Chem. Eng. 26, 75-87. doi:10.1016/j.apcatb.2004.06.014

Bali, U., Çatalkaya, E.Ç., Şengül, F., 2003. Photochemical Degradation and Mineralization of Phenol: A Comparative Study. J. Environ. Sci. Heal. Part A 38, 2259-2275. doi:10.1081/ESE-120023373

Benatti, C.T., Tavares, C.R.G., 2012. Fenton's process for the treatment of mixed waste chemicals, in: Organic Pollutants Ten Years After the Stockholm Convention - Environmental and Analytical Update. InTech, pp. $247-70$.

Benitez, F.J., Beltran-Heredia, J., Torregrosa, J., Acero, J.L., 1999. Treatment of olive mill wastewaters by ozonation, aerobic degradation and the combination of both treatments. J. Chem. Technol. Biotechnol. 74, 639-646. doi:10.1002/(SICI)1097-4660(199907)74:7<639::AID-JCTB92>3.0.CO;2-I

Benkelberg, H.-J., Warneck, P., 1995. Photodecomposition of Iron(II1) Hydroxo and Sulfato Complexes in Aqueous Solution: Wavelength Dependence of OH and sod- Quantum Yields. J. Phys. Chem. 99, 5214-5221. doi:10.1021/j100014a049

Bergmann, M.E.H., Koparal, a. S., Iourtchouk, T., 2014. Electrochemical Advanced Oxidation Processes, Formation of Halogenate and Perhalogenate Species: A Critical Review. Crit. Rev. Environ. Sci. Technol. 44, 348-390. doi:10.1080/10643389.2012.718948

Bolton, J.R., Bircher, K.G., Tumas, W., Tolman, C.A., 2001. Figures-of-merit for the technical development and application of advanced oxidation technologies for both electric- and solar-driven systems. Pure Appl. Chem. 73, 627-637. doi:10.1351/pac200173040627 
Bremner, D.H., Burgess, A.E., Houllemare, D., Namkung, K.-C., 2006. Phenol degradation using hydroxyl radicals generated from zero-valent iron and hydrogen peroxide. Appl. Catal. B Environ. 63, 15-19. doi:10.1016/j.apcatb.2005.09.005

Brillas, E., 2014. Electro-Fenton , UVA Photoelectro-Fenton and Solar Photoelectro-Fenton Treatments of Organics in Waters Using a Boron-Doped Diamond Anode : A Review. J. Mex. Chem. Soc. 58, 239-255.

Brillas, E., Garcia-Segura, S., 2020. Benchmarking recent advances and innovative technology approaches of Fenton, photo-Fenton, electro-Fenton, and related processes: A review on the relevance of phenol as model molecule. Sep. Purif. Technol. 237, 116337. doi:10.1016/j.seppur.2019.116337

Brillas, E., Sirés, I., Oturan, M.A., 2009. Electro-Fenton process and related electrochemical technologies based on Fenton's reaction chemistry. Chem. Rev. 109, 6570-6631. doi:10.1007/s00894-008-0358-0

Buxton, G. V, Greenstock, C.L., Helman, W.P., Ross, A.B., 1988. Critical review of rate constants for reactions of hydrated electrons, hydrogen atoms and hydroxyl radicals $(\cdot \mathrm{OH} / \bullet \mathrm{O}-)$ in aqueous solution. J. Phys. Chem. Ref. data 17, 513-886.

Cañizares, P., Paz, R., Sáez, C., Rodrigo, M. a, 2009. Costs of the electrochemical oxidation of wastewaters: a comparison with ozonation and Fenton oxidation processes. J. Environ. Manage. 90, 410-20. doi:10.1016/j.jenvman.2007.10.010

Castillo-Carvajal, L.C., Sanz-Martin, J.L., Barragan-Huerta, B.E., 2014. Biodegradation of organic pollutants in saline wastewater by halophilic microorganisms: A review. Environ. Sci. Pollut. Res. 21, 9578-9588. doi:10.1007/s11356-014-3036-Z

Chen, R., Pignatello, J.J., 1997. Role of Quinone Intermediates as Electron Shuttles in Fenton and Photoassisted Fenton Oxidations of Aromatic Compounds. Environ. Sci. Technol. 31, 2399-2406. doi:10.1021/es9610646

Degen, J., Nussberger, F.E., 1956. Notes on the Determination of Suspended Solids. Sewage Ind. Waste. 28, 237240. 
Deng, F., Olvera-Vargas, H., Garcia-Rodriguez, O., Qiu, S., Yang, J., Lefebvre, O., 2018. The synergistic effect of nickel-iron-foam and tripolyphosphate for enhancing the electro-Fenton process at circum-neutral $\mathrm{pH}$. Chemosphere 201, 687-696. doi:10.1016/j.chemosphere.2018.02.186

Flox, C., Garrido, J.A., Rodríguez, R.M., Cabot, P.-L., Centellas, F., Arias, C., Brillas, E., 2007. Mineralization of herbicide mecoprop by photoelectro-Fenton with UVA and solar light. Catal. Today 129, 29-36. doi:10.1016/j.cattod.2007.06.049

Ganiyu, S.O., Zhou, M., Martínez-huitle, C.A., 2018. Heterogeneous electro-Fenton and photoelectro-Fenton processes : A critical review of fundamental principles and application for water / wastewater treatment. Appl. Catal. B Environ. 235, 103-129. doi:10.1016/j.apcatb.2018.04.044

Garcia-Rodriguez, O., Mousset, E., Olvera-Vargas, H., Lefebvre, O., 2020. Electrochemical treatment of highly concentrated wastewater: A review of experimental and modeling approaches from lab- to full-scale. Crit. Rev. Environ. Sci. Technol. 0, 1-70. doi:10.1080/10643389.2020.1820428

Ghatak, H.R., 2013. Advanced Oxidation Processes for the Treatment of Biorecalcitrant Organics in Wastewater. Crit. Rev. Environ. Sci. Technol. 3389, 130828223136006. doi:10.1080/10643389.2013.763581

Girish, C.R., Murty, V.R., 2014. Adsorption of phenol from aqueous solution using Lantana camara, forest waste: kinetics, isotherm, and thermodynamic studies. Int. Sch. Res. Not. 1-16. doi:10.1007/s40710-015-0117-z

Goi, A., Trapido, M., 2002. Hydrogen peroxide photolysis, Fenton reagent and photo-Fenton for the degradation of nitrophenols: A comparative study. Chemosphere 46, 913-922. doi:10.1016/S0045-6535(01)00203-X

Huddersman, K., Ekpruke, A., Asuelimen, L., 2019. Application of AOPs in the treatment of OSPAR chemicals and a comparative cost analysis. Crit. Rev. Environ. Sci. Technol. 49, 277-317. doi:10.1080/10643389.2018.1537770

Leblebici, M.E., Stefanidis, G.D., Van Gerven, T., 2015. Comparison of photocatalytic space-time yields of 12 reactor designs for wastewater treatment. Chem. Eng. Process. Process Intensif. 97, 106-111. 
doi:10.1016/j.cep.2015.09.009

Lee, Y., Gerrity, D., Lee, M., Gamage, S., Pisarenko, A., Trenholm, R.A., Canonica, S., Snyder, S.A., Von Gunten, U., 2016. Organic Contaminant Abatement in Reclaimed Water by UV/H2O2 and a Combined Process Consisting of O3/H2O2 Followed by UV/H2O2: Prediction of Abatement Efficiency, Energy Consumption, and Byproduct Formation. Environ. Sci. Technol. 50, 3809-3819. doi:10.1021/acs.est.5b04904

Lefebvre, O., Shi, X., Tein, J.G., Ng, H.Y., 2013. Suitability of ozone pre-treatment for amoxicillin wastewater. Water Sci. Technol. 68, 2492-6. doi:10.2166/wst.2013.534

Liu, W., Andrews, S. a., Stefan, M.I., Bolton, J.R., 2003. Optimal methods for quenching H2O2 residuals prior to UFC testing. Water Res. 37, 3697-3703. doi:10.1016/S0043-1354(03)00264-1

Lucas, M.S., Peres, J. a., Li Puma, G., 2010. Treatment of winery wastewater by ozone-based advanced oxidation processes $(\mathrm{O} 3, \mathrm{O} 3 / \mathrm{UV}$ and $\mathrm{O} 3 / \mathrm{UV} / \mathrm{H} 2 \mathrm{O} 2)$ in a pilot-scale bubble column reactor and process economics. Sep. Purif. Technol. 72, 235-241. doi:10.1016/j.seppur.2010.01.016

Maciel, R., Sant'Anna Jr., G.L., Dezotti, M., 2004. Phenol removal from high salinity effluents using Fenton's reagent and photo-Fenton reactions. Chemosphere 57, 711-719. doi:10.1016/j.chemosphere.2004.07.032

Martínez-Huitle, C.A., Rodrigo, M.A., Sirés, I., Scialdone, O., 2015. Single and coupled electrochemical processes and reactors for the abatement of organic water pollutants : A critical review. Chem. Rev. 115, 13362-13407. doi:10.1021/acs.chemrev.5b00361

Miklos, D.B., Remy, C., Jekel, M., Linden, K.G., Drewes, J.E., Hübner, U., 2018. Evaluation of advanced oxidation processes for water and wastewater treatment - A critical review. Water Res. 139, 118-131. doi:10.1016/j.watres.2018.03.042

Moreira, F.C., Boaventura, R.A.R., Brillas, E., Vilar, V.J.P., 2017. Electrochemical advanced oxidation processes: A review on their application to synthetic and real wastewaters. Appl. Catal. B Environ. 202, 217-261. doi:10.1016/j.apcatb.2016.08.037 
Mousset, E., Frunzo, L., Esposito, G., Hullebusch, E.D. van, Oturan, N., Oturan, M.A., 2016a. A complete phenol oxidation pathway obtained during electro-Fenton treatment and validated by a kinetic model study. Appl. Catal. B Environ. 180, 189-198. doi:10.1016/j.apcatb.2015.06.014

Mousset, E., Huang Weiqi, V., Foong Yang Kai, B., Koh, J.S., Tng, J.W., Wang, Z., Lefebvre, O., 2017a. A new 3D-printed photoelectrocatalytic reactor combining the benefits of a transparent electrode and the Fenton reaction for advanced wastewater treatment. J. Mater. Chem. A 5, 24951-24964. doi:10.1039/C7TA08182K

Mousset, E., Oturan, N., Oturan, M.A., 2018a. An unprecedented route of $\mathrm{OH}$ radical reactivity evidenced by an electrocatalytical process: Ipso-substitution with perhalogenocarbon compounds. Appl. Catal. B Environ. 226, 135-146. doi:10.1016/j.apcatb.2017.12.028

Mousset, E., Oturan, N., van Hullebusch, E.D., Guibaud, G., Esposito, G., Oturan, M.A., 2014. Treatment of synthetic soil washing solutions containing phenanthrene and cyclodextrin by electro-oxidation. Influence of anode materials on toxicity removal and biodegradability enhancement. Appl. Catal. B Environ. 160-161, 666-675. doi:10.1016/j.apcatb.2014.06.018

Mousset, E., Pechaud, Y., Oturan, N., Oturan, M.A., 2019. Charge transfer/mass transport competition in advanced hybrid electrocatalytic wastewater treatment: Development of a new current efficiency relation. Appl. Catal. B Environ. 240, 102-111. doi:10.1016/j.apcatb.2018.08.055

Mousset, E., Pontvianne, S., Pons, M.-N., 2018b. Fate of inorganic nitrogen species under homogeneous Fenton combined with electro-oxidation/reduction treatments in synthetic solutions and reclaimed municipal wastewater. Chemosphere 201, 6-12. doi:10.1016/j.chemosphere.2018.02.142

Mousset, E., Quackenbush, L., Schondek, C., Gerardin-Vergne, A., Pontvianne, S., Kmiotek, S., Pons, M.N., 2020. Effect of homogeneous Fenton combined with electron transfer on the fate of inorganic chlorinated species in synthetic and reclaimed municipal wastewater. Electrochim. Acta 334, 135608. doi:10.1016/j.electacta.2019.135608 
Mousset, E., Trellu, C., Olvera-Vargas, H., Pechaud, Y., Fourcade, F., Oturan, M.A., 2021. Electrochemical technologies coupled with biological treatments. Curr. Opin. Electrochem. 26, 100668. doi:https://doi.org/10.1016/j.coelec.2020.100668

Mousset, E., Wang, Z., Hammaker, J., Lefebvre, O., 2017b. Electrocatalytic phenol degradation by a novel nanostructured carbon fiber brush cathode coated with graphene ink. Electrochim. Acta 258, 607-617. doi:10.1016/j.electacta.2017.11.104

Mousset, E., Wang, Z., Hammaker, J., Lefebvre, O., 2016b. Physico-chemical properties of pristine graphene and its performance as electrode material for electro-Fenton treatment of wastewater. Electrochim. Acta 214, 217-230. doi:10.1016/j.electacta.2016.08.002

Mousset, E., Wang, Z., Lefebvre, O., 2016c. Electro-Fenton for control and removal of micropollutants - process optimization and energy efficiency. Water Sci. Technol. 74, 2068-2074.

Mousset, E., Wang, Z., Olvera-Vargas, H., Lefebvre, O., 2018c. Advanced electrocatalytic pre-treatment to improve the biodegradability of real wastewater from the electronics industry - A detailed investigation study. J. Hazard. Mater. 360, 552-559. doi:10.1016/j.jhazmat.2018.08.023

Mvula, E., Von Sonntag, C., 2003. Ozonolysis of phenols in aqueous solution. Org. Biomol. Chem. 1, 1749-1756. doi:10.1039/b301824p

Nidheesh, P. V., Divyapriya, G., Oturan, N., Trellu, C., Oturan, M.A., 2019. Environmental applications of borondoped diamond electrodes: 1. Applications in water and wastewater treatment. ChemElectroChem 6, 1-20. doi:10.1002/celc.201801876

Okamoto, K., Yamamoto, Y., Tanaka, H., Tanaka, M., Itaya, A., 1985. Heterogeneous photocatalytic decomposition of phenol over TiO2 powder. Bull. Chem. Soc. Jpn. 58, 2015-2022.

Oller, I., Malato, S., Sánchez-Pérez, J.A., 2011. Combination of Advanced Oxidation Processes and biological treatments for wastewater decontamination-A review. Sci. Total Environ. 409, 4141-4166. 
doi:10.1016/j.scitotenv.2010.08.061

Olvera-Vargas, H., Cocerva, T., Oturan, N., Buisson, D., Oturan, M.A., 2016. Bioelectro-Fenton: A sustainable integrated process for removal of organic pollutants from water: Application to mineralization of metoprolol. J. Hazard. Mater. 319, 13-23. doi:10.1016/j.jhazmat.2015.12.010

Oturan, M.A., Aaron, J.-J., 2014. Advanced Oxidation Processes in Water/Wastewater Treatment: Principles and Applications. A Review. Crit. Rev. Environ. Sci. Technol. 44, 2577-2641. doi:10.1080/10643389.2013.829765

Panizza, M., Cerisola, G., 2009. Direct and mediated anodic oxidation of organic pollutants. Chem. Rev. 109, 6541-6569. doi:10.1021/cr9001319

Panizza, M., Michaud, P. a., Cerisola, G., Comninellis, C., 2001. Anodic oxidation of 2-naphthol at boron-doped diamond electrodes. J. Electroanal. Chem. 507, 206-214. doi:10.1016/S0022-0728(01)00398-9

Pignatello, J.J., Liu, D., Huston, P., 1999. Evidence for an additional oxidant in the photoassisted Fenton reaction. Environ. Sci. Technol. 33, 1832-1839. doi:10.1021/es980969b

Pimentel, M., Oturan, N., Dezotti, M., Oturan, M.A., 2008. Phenol degradation by advanced electrochemical oxidation process electro-Fenton using a carbon felt cathode. Appl. Catal. B Environ. 83, 140-149. doi:10.1016/j.apcatb.2008.02.011

Prieto-Rodríguez, L., Oller, I., Klamerth, N., Agüera, A., Rodríguez, E.M., Malato, S., 2013. Application of solar AOPs and ozonation for elimination of micropollutants in municipal wastewater treatment plant effluents. Water Res. 47, 1521-1528. doi:10.1016/j.watres.2012.11.002

Rahmani, A., Samadi, M., Enayati Moafagh, a, 2008. Investigation of Photocatalytic Degradation of Phenol by UV/TiO2 Process in Aquatic Solutions. J. Res. Health Sci. 8, 55-60.

Rakness, K., Gordon, G., Langlais, B., 1996. Guideline for measurement of ozone concentration in the process gas from an ozone generator. 
Rizzo, L., Gernjak, W., Krzeminski, P., Malato, S., McArdell, C.S., Perez, J.A.S., Schaar, H., Fatta-Kassinos, D., 2020. Best available technologies and treatment trains to address current challenges in urban wastewater reuse for irrigation of crops in EU countries. Sci. Total Environ. 710, 136312. doi:10.1016/j.scitotenv.2019.136312

Rodríguez, M., 2003. Fenton and UV-vis based advanced oxidation processes in wastewater treatment: Degradation, mineralization and biodegradability enhancement 296.

Ruppert, G., Bauer, R., Heisler, G., 1993. The photo-Fenton reaction — an effective photochemical wastewater treatment process. J. Photochem. Photobiol. A Chem. 73, 75-78. doi:10.1016/1010-6030(93)80035-8

Saien, J., Shahrezaei, F., 2012. Organic pollutants removal from petroleum refinery wastewater with nanotitania photocatalyst and UV light emission. Int. J. Photoenergy 2012. doi:10.1155/2012/703074

Sgroi, M., Snyder, S.A., Roccaro, P., 2021. Comparison of AOPs at pilot scale: Energy costs for micro-pollutants oxidation, disinfection by-products formation and pathogens inactivation. Chemosphere 273, 128527. doi:10.1016/j.chemosphere.2020.128527

Sirés, I., Brillas, E., Oturan, M.A., Rodrigo, M.A., Panizza, M., 2014. Electrochemical advanced oxidation processes: today and tomorrow. A review. Environ. Sci. Pollut. Res. 21, 8336-8367. doi:10.1007/s11356014-2783-1

Stefan, M.I. (Ed.), 2017. Advanced oxidation processes for water treatment: fundamentals and applications. IWA Publishing, London, UK.

Sun, Y., Pignatello, J.J., 1993. Photochemical reactions involved in the total mineralization of 2,4-D by iron(3+)/hydrogen peroxide/UV. Environ. Sci. Technol. 27, 304-310. doi:10.1021/es00039a010

Wang, W., Serp, P., Kalck, P., Faria, J.L., 2005. Visible light photodegradation of phenol on MWNT-TiO2 composite catalysts prepared by a modified sol-gel method. J. Mol. Catal. A Chem. 235, 194-199. doi:10.1016/j.molcata.2005.02.027 
Yao, W., Ur Rehman, S.W., Wang, H., Yang, H., Yu, G., Wang, Y., 2018. Pilot-scale evaluation of micropollutant abatements by conventional ozonation, UV/O3, and an electro-peroxone process. Water Res. 138, 106-117. doi:10.1016/j.watres.2018.03.044 